\title{
Rights and Value: Construing the International Covenant on Economic, Social and Cultural Rights as Civil Commons
}

\author{
GIORGIO BARUCHELLO* \& RACHAEL LORNA JOHNSTONE** \\ *Faculty Social Sciences, Háskólinn á Akureyri/University of Akureyri, Akureyri, Iceland, **Faculty of \\ Law, Háskólinn á Akureyri/University of Akureyri, Akureyri, Iceland.
}

\begin{abstract}
This article brings together the United Nations' International Covenant on Economic, Social and Cultural Rights (ICESCR) and John McMurtry's theory of value. In this perspective, the ICESCR is construed as a prime example of "civil commons," while McMurtry's theory of value is proposed as a tool of interpretation of the covenant. In particular, McMurtry's theory of value is a hermeneutical device capable of highlighting: (a) what alternative conception of value systemically operates against the fulfilment of the rights enshrined in the ICESCR; (b) the increased relevance of the ICESCR with regard to the current global economic crisis; (c) the parameters to determine the degree to which the rights at issue have been realized. Reflections on environmental implications of both the ICESCR and McMurtry's axiology conclude the article.
\end{abstract}

\section{Introduction}

Law and philosophy have met each other happily on many occasions. Indeed, jurisprudence, legal theory and, to a relevant extent, constitutional law are nothing but a combination of legal and philosophical concerns, aims, conceptions, and methodologies. However, as far as the present authors are aware, there has been hitherto no attempt whatsoever to bring together the 1966 International Covenant on Economic, Social and Cultural Rights (ICESCR) and John McMurtry's lifegrounded onto-axiology, a specific theory of value. ${ }^{1}$ Such a coupling, as the following pages will show, does not constitute a futile academic exercise. Rather, the ICESCR can serve as a prime example of "civil commons," that is to say an original philosophical conception of McMurtry's that is entering the mainstream of the nomenclature of today's Anglophone social scientists and humanists and, on occasion, institutional practice (e.g. Dartmouth Common Master Plan, 2009). ${ }^{2}$

At the same time, McMurtry's theory of value can provide the theoretical underpinning required for a more nuanced understanding and perhaps a theoretical

Correspondence Address: Georgio Baruchello, Faculty of Social Sciences, University of Akureyri, Iceland. Email: giorgio@unak.is

Rachael Lorna Johnstone, Faculty of Law, University of Akureyri, Iceland. Tel: +354 460 8666, Email: rlj@unak.is

ISSN: 1911-4788 
framework for interpreting the ICESCR. McMurtry's work enables us to unpack the legal principles of the ICESCR as the real content of social justice: guaranteed access to those goods and institutions needed by human beings to survive, develop, and live good lives. McMurtry's work has not to our knowledge been analysed from a human rights perspective, but it too is well recognized within the UN network, having been adopted as the philosophical perspective within UNESCO's Encyclopedia of Life Support Systems (EOLSS). In what follows we will analyse the ICESCR from the standpoint of McMurtry's life-value onto-axiology, emphasising throughout how it gives legal substance to the core values of McMurtry's life-grounded understanding of social justice. ${ }^{3}$

Before proceeding to the coupling of the ICESCR and McMurtry's axiology, an introduction to each will be provided. Subsequently, McMurtry's theory of value will be utilized to reveal: (a) what alternative conception of value systemically operates today against the fulfilment of the rights enshrined in the ICESCR; (b) the increased relevance of the ICESCR with regard to the current global economic crisis; (c) the parameters to determine the degree to which the rights at issue have been realized, (a) notwithstanding. Reflections on the environmental implications of both the ICESCR and McMurtry's axiology conclude the article.

\section{Introduction to the ICESCR}

A human rights chapter was not included within the 1945 UN Charter itself but the Economic and Social Council established under the Charter was entrusted to set up "commissions in economic and social fields and for the promotion of human rights" (article 68). At its first meeting in 1946, it established the Commission on Human Rights (CHR), with which it entrusted the task of drafting a binding treaty on human rights law, as well as the Commission on the Status of Women. In 1948, the United Nations' Commission on Human Rights agreed and submitted to the General Assembly the Universal Declaration of Human Rights (UDHR), where it was approved with no negative votes. ${ }^{4}$ However, the UDHR is not a treaty and therefore not in itself legally binding. The UDHR was expected to form the foundation for a treaty to which states could commit themselves, but during a process that took nearly two decades, two, not one, treaties emerged: the ICESCR and the International Covenant on Civil and Political Rights (ICCPR). It was another ten years before they would come into force (Whelan \& Donnelly, 2007).

Modern readings often interpret the division of the UDHR into two distinct treaties as cold-war politics: the West was suspicious of economic, social, and cultural rights qua rights; the East considered them as more fundamental than civil and political rights (Arbour, 2006; Tomasevski, 2005). The truth is, as usual, more nuanced and the UDHR owes the breadth of its content in some measure to the United States of America and in particular Roosevelt's "four freedoms" (Alfredsson \& Eide, 1999; Eide, 2001; Whelan \& Donnelly, 2007). Western states and traditional allies of the United States, including Australia, Canada, Germany and the United Kingdom were amongst the first state parties to the ICESCR. However, having signed the covenant during the Carter presidency, American resistance to the ICESCR was only consolidated during the Reagan administration (Alston, 2009).

Studies in Social Justice, Volume 5, Issue 1, 2011 
The transformation of the UDHR into two legally binding treaties, rather than one, was intended to address not so much differences of opinion about the relative importance of different rights but more pragmatic concerns about implementation: in particular, state capability and institutional justiciability (Alfreddson \& Eide, 1999; Whelan \& Donnely, 2007). To the extent that fulfilment of economic, social, and cultural rights had significant budgetary implications, it was not self-evident that the courts were the proper fora for such fine assessments (Alfredsson \& Eide, 1999). Yet, it was pointed out that economic, social, and cultural rights were no different from civil and political rights in this regard in that both groups contain both positive and negative elements, or, in the common parlance of the United Nations Committee on Economic, Social and Cultural Rights (ESCR Committee), established to monitor state compliance with the ICESCR, duties to respect, protect, and fulfil (Alston \& Quinn, 1987; Craven, 1995; Scott \& Macklem,1992). Civil and political rights likewise require state expenditures (Certification case, 1996, para. 77). From the standpoint of a life-grounded understanding both are equally essential as what any just society must guarantee to each of its citizens.

Still, at the time of drafting, it was obvious that a number of states were in no position to guarantee overnight all the economic, social, and cultural rights promised in the UDHR but they were better equipped to facilitate civil and political rights. In most states, in 1966, there was already in place a rudimentary framework that could ensure even those civil and political rights that require extensive state investment, such as the right to a fair trial or the right to vote. In other words, the overwhelming majority of states had operational courts, functioning judiciaries and could hold rudimentary elections. Yet, most were very far from guaranteeing adequate housing or health-care facilities for everyone, nor could any such infrastructure be built in the anticipated three months period between ratification and entry into force (Alfredsson \& Eide, 1999; Whelan \& Donnely, 2007). Thus, whilst states agreed under the ICCPR to guarantee civil and political rights to the full immediately, they agreed only to work towards full enjoyment of economic, social, and cultural rights, i.e. they undertook the obligation to "progressively realize" these rights. ${ }^{5}$

The progressive realization standard solved the capability problem: states had to take all appropriate means-within their means - to realize the rights in the ICESCR. However, this formulation brought with it its own set of problems, in particular, the justiciability problem. How could courts adjudicate the satisfaction or violation of rights that lacked explicit benchmarks, that were effectively contextual and which depended on the relative means of each state party? If there is no absolute obligation on the state, how can it be determined if the state has breached its obligation?

In reply, we would point to numerous rights within the ICESCR which are not vague at all, such as the right to join a trade union of one's choice and the right not to be discriminated against in respect of economic, social, and cultural rights (ICESCR, 1966, articles 8 and 2(2)). On the other hand, there are likewise rights within the ICCPR that are inherently vague and subject to contextual interpretation such as the right to privacy which can be subject to "lawful" and "non-arbitrary" interference and must be balanced against freedom of expression (ICCPR, 1966, articles 14, 18 and 19(2); Scott \& Macklem, 1992).

With regard to more complex rights, two decades of output from the ESCR Committee has provided ever greater clarity and precision as to what is required of state parties and adjudication by the Committee under the new communications 
process will further enrich understanding (OP-ICESCR, 2008). ${ }^{6}$ Economic, social, and cultural rights have been introduced into modern constitutions and are regularly adjudicated by judges all over the World, most famously in South Africa. ${ }^{7}$ The justiciability horse needs no more flogging here. ${ }^{8}$

The ESCR Committee is not a creature of the ICESCR, in contrast to its counterpart, the Human Rights Committee, established under the ICCPR (article 28). Instead, the ESCR Committee was established nearly ten years after the Covenant came into force, on the back of resolution nr. 1985/17 by the United Nations Economic and Social Council (ECOSOC). Like the Human Rights Committee, it reviews state reports, discusses them with state parties and makes concluding observations, and it issues general comments addressed to all state parties (Langford \& King, 2009).

If the heart of the ICCPR is the "right to life" (article 6), the heart of the ICESCR might be considered the "right to live" i.e. the right to live a dignified life; the right to a quality of life; the right to a life free of fear of hunger and destitution; a life where the human spirit has space to flourish. This flourishing, which is contingent upon the comprehensive satisfaction of the needs recognized by the 'right to live' is the ultimate goal of life-grounded social justice. Genuine fulfilment of the covenant requires realization of many of the values that are at the heart of modern conceptions of "social justice," such as access to fair employment, education, and healthcare provision.

The substantive provisions of the ICESCR include: the right to self-determination of peoples, including the right to control their own natural resources (article 1); the right to work (article 6); the right to just and favourable conditions of work, including remuneration (article 7); the right to trade union organization and participation (article 8); the right to social security (article 9); the right to recognition and protection of marriage and paid leave for new mothers (article 10); the right to an adequate standard of living, including adequate food, clothing, and housing (article 11); the right to the highest attainable standard of health (article 12); the right to education (articles 13-14); and the right to take part in cultural life, to benefit from scientific progress and to benefit from one's own intellectual creations (article 15). Overlying these rights is the principle of non-discrimination (article 2(2)), with gender equality emphasized (article 3), the prohibition of abuse of rights (article 5), and the permission for states to set limits on the enunciated rights only "for the purposes of promoting the general welfare in a democratic society” (article 4).

As an international treaty, the ICESCR is unquestionably binding as a matter of international law (VCLT article 26). Nevertheless, state practice does not always conform to states' obligations. Indeed, alternative or even incompatible normative frameworks can shape the discourse. To name just a few examples vis-à-vis articles 1, 6, 12 and 13 respectively: (a) in 2009, the government of Peru responded by means of police and military crackdowns to protests by indigenous populations against the legislation that opened Peru's virgin forests to oil- and gas-drilling operations (Cordero, 2009); (b) in 2010, unemployment in the Eurozone reached double figures; but the European Central Bank engaged in no quantitative easing to counteract this trend, comparable to the steps taken between 2007 and 2009 to rescue failing private banks (OECD, 2010); (c) in the past biennium, the adoption of a universal healthcare coverage in the United States of America has been vocally

Studies in Social Justice, Volume 5, Issue 1, 2011 
opposed by mobilized individuals that dub themselves the "Tea Party" movement, and whose number and influence are reshaping the Republican Party (Espo, 2010); (d) plans are being unveiled in the British Parliament to slash education funding at tertiary level at English and Welsh universities, which are therefore likely to take in fewer students in the future and demand higher tuition fees (Vasagar, 2010). Apart from suggesting that governmental authorities neglect the covenants to which they are bound, the examples above signal that alternative conceptions of value exist and may even be predominant in politics and institutional life, to the point of rejecting the rights enshrined in international law. How are such views to be assessed? Do they imply that the values embodied by the ICESCR are incomplete? In pluralist societies such as ours, which values should be upheld and, above all, upon what grounds? In the following sections, we will show how the work of McMurtry can help to answer some of these deep and controversial questions.

\section{Introduction to John McMurtry’s Axiology}

Possibly terrified by the consequences of the uncompromising statements of value characterizing totalitarian ideologies, all "classic" Anglophone theorists of value of the second half of the 20th century have offered highly abstract and impractical interpretations. ${ }^{9}$ Whether intentionally or not, these interpretations have reflected the dominant liberal economic conception of value of their age, whereby the "preference satisfaction" of the contract-stipulating individual determines value by the exercise of allegedly universal and neutral money-demand in the so-called "free market." Thus understood, value is ultimately subjective (i.e. different individuals have different values), atomistic (i.e. societies' values are aggregates of individuals' values) and quintessentially human (i.e. human beings ascribe value to non-human beings, which would otherwise possess none).

McMurtry (2009-10) is aware of the perplexities that arise regularly with regard to any objective determination of value: "As the recent history of philosophy discloses, the multiplying particular bearings of language games, specific practices, incommensurable epistemic perspectives, anti-foundationalist conversations and poststructural principles of difference have overwhelmed the very idea of a unifying value system, good or ill, as inconceivable to acceptable meaning” (para. 1.10.4). ${ }^{10}$ Nevertheless, after pondering upon the recurrent "meltdowns" of the post-BrettonWoods age and the social and ecological losses accompanying them, he claims that we must: "follow reason where it leads to recover step by step the missing lifeground of values and the ultimate meaning of how we are to live” (para. 1.16). Since the formal and relativist options debated in mainstream axiology have proven tragically useless vis-à-vis both economic and ecological crises, he endeavours to provide a substantial and objective alternative. ${ }^{11}$ Yet what exactly is the "lifeground" that has gone amiss and that, if recovered, can reveal how we should live?

The definition of this key-term is unusually simple to grasp: "Concretely, all that is required to take the next breath; axiologically, all the life support systems required for human life to reproduce or develop” (McMurtry, 2009-10, Glossary). ${ }^{12}$ Without enough bread, clean water, breathable air, open spaces in which to move, regular sleep, acceptable education and meaningful socialization, no value whatsoever that we cherish will ever be expressed in reality. ${ }^{13}$ Here the life-ground works beneath 
established ideological and philosophical disputes about the meaning of social justice to expose its material core in the satisfaction of human life-requirements. All values with no exception, whether ethical, political, economic, epistemic or aesthetic, rely upon this vital platform-the life-ground-typically in a pre-reflexive manner. ${ }^{14}$ There can be no life, not to mention any good life, outside this ground. As McMurtry (2009-10) states, "Life support systems - any natural or human-made system without which human beings cannot live or live well-may or may not have value in themselves, but have ultimate value so far as they are that without which human or other life cannot exist or flourish" (para. 6.2.1). ${ }^{15}$ Even the civil and political rights enshrined in liberal democratic constitutions and in the ICCPR itself-be they justice, equality, liberty, or democracy—are formal fictions if the prerequisites for prolonged survival and adequate individual and social existence are not met. As eloquently stated forty years ago by liberal icon Isaiah Berlin (1969): "It is true that to offer political rights, or safeguards against intervention by the state, to men who are half-naked, illiterate, underfed, and diseased is to mock their condition... What is freedom to those who cannot make use of it? Without adequate conditions for the use of freedom, what is the value of freedom?” (p. 124).

McMurtry calls "needs" these prerequisites, the scrutiny of which serves then the end of clarifying the composition and the scope of the life-ground. ${ }^{16}$ Not anything that we may claim to "need" is, after closer scrutiny, a need. ${ }^{17}$ According to McMurtry (1998), “' $n$ ' is a need if and only if, and to the extent that, deprivation of $n$ always leads to a reduction of organic capacity" (p. 164) ${ }^{18}$ Only that without which organic capacity is harmed regularly and unequivocally counts as need. We can live, and even prosper, without motorbikes or memory pens, but we cannot live, not to mention prosper, without nourishing food, shelter and several hours of sleep per night. Upon such needs and their prolonged, secure satisfaction rests everything else that may be regarded as valuable: art, sport, conversation, commerce, scientific research, sexual experimentation, political activism, philosophical meditation, etc. And whenever any such derivative form of agency harms or hampers the prolonged, secure, universal satisfaction of needs, then disvalue ensues. ${ }^{19}$

Whilst the recognition of human needs by McMurtry is an important beginning, the satisfaction of human needs is not the same as the recognition of human rights to the satisfaction of the same. Needs should not be met by the state as a matter of welfare, a matter of charity, which the state enjoys discretion to withdraw. A citizen should not beg for the assistance necessary simply to stay alive; instead they should be able to demand that their needs be met and, moreover, have confidence that their needs will continue to be met. "To enjoy something only at the discretion of someone else, especially someone powerful enough to deprive you of it at will, is precisely not to enjoy a right to it” (Shue as cited in Skogly, 1993, p. 769). Holding a right is a special sort of entitlement for which there is no shame attached to its claiming; and it is an entitlement that remains notwithstanding budgetary uncertainty or constraints on the duty bearer.

Given that McMurtry (2009-10) regards life as unfolding along three modes of ontological manifestation-i.e. "thought," "experience" (also "feeling" or "felt being”), and "action" (also "biological movement" or "motility") ${ }^{20}$-the fundamental coordinates of value are as follows (italics in the original):

Studies in Social Justice, Volume 5, Issue 1, 2011 
- " $X$ is value if and only if, and to the extent that, $x$ consists in or enables a more coherently inclusive range of thought/feeling/action than without it" (para. 6.1);

- " $x$ is disvalue if and only if, and to the extent that, $x$ reduces/disables any range of thought/experience/action" (para. 6.1). ${ }^{21}$

Devoid of a theoretical underpinning as comprehensively abstract as McMurtry's life-ground — the attainment of which is after all the philosopher's raison d'être- the world's nations have provided themselves with an array of concepts, traditions, collective praxes, facilities, charities, foundations, and disciplinary branches whose main task is enable to foster life capacity expression and enjoyment. Ethical principles, notions of the common good, human rights, life-expectancy rates, hygiene standards, methods for waste disposal, suicide rates, manic-depressive pathologies, crime rates, literacy levels and many other dimensions of individual, social and natural existence have been conceptualized, discussed, followed, scrutinized, addressed and managed daily by corresponding institutions, such as ethical committees, scholarly communities, human rights treaty bodies, municipal registrars, public hygiene offices, mental hygiene departments, police corps and other law-andorder enforcers, schools, research centres, etc. ${ }^{22}$ Whether conscious or not of their life-serving function, much of organized human existence, both material and immaterial, has been spent in view of conceiving, perceiving, preventing, denouncing, and countering any assault on life capacity, as this is revealed by the particular, standardized indicators that are specific to each institution. ${ }^{23}$

McMurtry (1999) lists a vast and diverse array of conceptions, arrangements and artefacts aimed at fulfilling these paramount ends in most diverse socio-historical contexts:

\begin{abstract}
[U]niversal health plans, the world wide web, common sewers, international outrage over Vietnam or Ogoniland, sidewalks and footpaths, the Chinese concept of jen, the Jubilee of Leviticus... water fountains, Robin Hood of Sherwood Forest, the air we breathe, effective pollution controls... music... old age pensions, universal education, Sweden's common forests... the second commandment of Yeshua... the rule of law, child and women shelters, parks, public broadcasting, clean water... the UN Declaration of Human Rights, occupational health and safety standards, village and city squares, the Brazilian rainforests, inoculation programmes, indigenous story-telling, the Ozone Protocol, the Tao, the peace movement, death rituals, animal rights agencies, community fishhabitats, food and drug legislation, garbage collection, the ancient village commons before enclosures. (pp. 206-207)
\end{abstract}

All of these human creations are "civil commons" i.e. "[a] unifying concept to designate social constructs which enable universal access to life goods. Life support systems [cf. note 5] are civil commons so far as society protects and enables their reproduction and provision for all members” (McMurtry, 2009-10, Glossary).

The predicate "civil" used in McMurtry's phrase reveals the socially constructed and socially aimed dimensions of the commons. ${ }^{24}$ McMurtry is not talking, say, of pastures available to all without supervision and sanctions for misuse, but of pastures that the community recognizes and manages to yield life-supporting fruits for the 
whole community through time. ${ }^{25}$ As a consequence, McMurtry's notion should not be confused with Garrett Hardin's (1968) unregulated natural "commons," whose tragic doom justifies their appropriation for private ends. On the contrary, McMurtry's works are, usually, critical of such an appropriation, inasmuch as it has taken place for class or elite benefit (e.g. $19^{\text {th }}$-century Highland clearances [Richards, 2000]) and/or converted the existing civil commons into means of non-universal (e.g. 1999 privatization schemes of water resources in South Africa [Pauw, 2003] and elsewhere [Roberts, 2006]) and/or non-life-enabling ends (e.g. the use of scientific knowledge for the production of biological weapons), thus perverting their original function. Historical examples of this perversion abound, as highlighted by the numerous tokens of resistance to each, e.g. the English peasantry's revolts against early-Renaissance enclosures, the anti-colonial Catholic-Communist Costa Rican social legislation of the 1940s-70s, recent EU-wide protests against the Bolkenstein directive, contemporary non-governmental organizations' (NGOs) demands for the re-regulation of de-regulated speculative trade of peoples' currencies.

\section{Different Economic Systems, the Life-Ground, and the ICESCR}

McMurtry's negative emphasis on privatization and his positive emphasis on the commons might suggest that he is a member of the Marxist camp, to which he did in fact contribute a significant piece of research (McMurtry, 1978) at the beginning of his long scholarly career (McMurtry, 2008). However, since the civil commons are meant to guarantee universal access to life goods, McMurtry departs from the Marxist tradition, which focuses on guaranteeing access to the means of production of life goods to a numerically predominant yet specific social class. Also, by linking the notion of civil commons to that of need, McMurtry presumes no framework of historical necessity, as with Marx's structural laws of socio-economic development, but rather a framework of biological necessity alone, i.e. no matter what our beliefs and preferences may be, we are going to suffer reduction of organic capacity and eventually death if we do not meet our vital needs. Departing further from the Marxist paradigm, McMurtry's emphasis upon biological necessity opens value judgments to domains of existence completely neglected by the Marxist canon, such as planetary ecosystems and the Earth's biosphere. Finally, McMurtry's approach does not even imply the abandonment of today's free market economies, which mix already liberal elements (e.g. freedom of contract between companies manufacturing armaments and the engineers that they employ) and socialist ones (e.g. state-funded bailouts of bankrupt private companies), but its effective regulation according to lifegrounded criteria (e.g. careful and consistent implementation of food-and-health regulations in for-profit food manufacturing).

From a life-grounded perspective, which system of ownership, management and trade ought to be predominant is not relevant per se, as an ideological, ethical or political summum bonum. ${ }^{26}$ Similarly, and in contrast to many international agreements of recent decades, the ICESCR is neither a trade agreement presupposing significant degrees of free-market activity, legal frameworks and economic policies; nor does it depend upon free-market activity or any particular legal framework or economic policies. The ESCR Committee has taken care to point out that the treaty

Studies in Social Justice, Volume 5, Issue 1, 2011 
does not exclude a libertarian model as long as everyone's rights are in fact fulfilled, noting in 1990 that:

[T]he undertaking "to take steps... by all appropriate means including particularly the adoption of legislative measures" neither requires nor precludes any particular form of government or economic system being used as the vehicle for the steps in question, provided only that it is democratic and that all human rights are thereby respected. Thus, in terms of political and economic systems, the Covenant is neutral and its principles cannot accurately be described as being predicated exclusively upon the need for, or the desirability of a socialist or a capitalist system, or a mixed, centrally planned, or laissez-faire economy, or upon any particular approach. (General Comment No. 3, 1990, para. 8)

It is thus quite reasonable for the state to assume that individuals will be able to a large extent to satisfy their own rights, with a minimum of state intervention. For example, individuals should be likely to be able to satisfy their rights to work and to an adequate standard of living, with the state only stepping in for those who are unable to do so independently (Alfredsson \& Eide, 1999). There is one notable exception in the treaty: the right to education, which, at least at primary level, must be compulsory and free (ICESCR, 1966, articles 13(2)(a) and 14).

In practice, the ESCR Committee's ecumenical approach to market systems only goes so far; a state party is not simply empowered to intervene to guarantee the relevant rights for its inhabitants but is obliged so to do when a dogmatically antiinterventionist approach leaves some individuals unable to secure their own economic, social, and cultural rights. For example, concluding the review of the report on Hong Kong in 2001, the Committee considered that the region's reliance “on the philosophy of 'positive non-interventionism'” was a factor limiting the full implementation of the treaty and "had a negative impact on the realization and enjoyment of the economic, social, and cultural rights of Hong Kong's inhabitants, which has been exacerbated by globalization" (ESCR Committee, 2002, p. 176). Similarly, the committee has expressed the view that increasing privatization of services has been accompanied by increasing challenges for certain groups of vulnerable individuals to satisfy their own basic rights; hence increasing responsibilities for state parties to intervene to ensure their rights are guaranteed qua rights (Craven, 1995).

From a life-grounded perspective, if the appropriation of the commons for private ends is preferred and performed, as ceaselessly done worldwide in the past three decades, it is crucial that it be able to spur life-capability more widely in both space and time. ${ }^{27}$ From such a perspective, an economy is truly successful if it can "secure provision of means of life otherwise in short supply (i.e. the production and distribution of goods and the protection of ecosystem services which are otherwise scarce or made scarce through time)" (McMurtry, 2005). Consistently, true "civil commons" are only those life-support systems that genuinely allow for such an economy to operate. Since life is the value-compass utilized by McMurtry, not any priced commodity contributing to the generation of profit or to augmented GrossDomestic-Product (GDP) figures should be counted as wealth-creation: "Claimed 'economic goods' which disable or do not enable life abilities are not means of life; they are economic 'bads'” (McMurtry, 2005). Carcinogenic pesticides, cluster 
bombs, junk commodities, speculative financial products and hazardous mining are not good. They are bad. They may be extremely profitable, like slaves had been for many centuries, but inasmuch as they reduce life-capacity, they are "goods" if and only if we wish to indulge in oxymoron. ${ }^{28}$

Perplexingly, standard economics endorses unflinchingly such an oxymoronic language. ${ }^{29}$ All life-reducing items of trade mentioned above are called, in standard economic language and praxis, "goods," with no exception. This glaring conceptual confusion, whereby nourishing bread is equated with golden toilets, can take place because in a value-system devoid of life-coordinates all that which does not compute as an item of trade in the free market is marginal or de facto invisible unless it is reconstructed as monetary loss or business opportunity (Baruchello, 2007a, 2008). Non-moneyed people, cultural homogenization, pollution, the loss of biodiversity, and the melting of the Arctic ice-shelf are economic "externalities" until, say, reduced cost of labour, carbon trade mechanisms, medical research, and lawsuits by indigenous communities seeking compensation make them expressible in moneybased terms. It is only whether and when the "externalities" can be "internalized" that economic calculus can actually compute them in its equations. This externalization of living beings and life support systems takes place regularly even if no economic calculus can actually exist without many of them and, in reality, presupposes several "externalities" throughout (e.g. the generation of children, human languages, Earth's breathable air and oceanic plankton). ${ }^{30}$ As soon as this "internalization" occurs, any item may become a tradable "good," even if the former "externality" has not been reconstructed as life-serving civil commons, but rather as a non-universal and even life-damaging for-profit activity (e.g. unnecessary stressinducing medical testing of paying pregnant women, disappearance of traditional birthday songs from films and plays due to copyright attribution, exclusive air stations in polluted Asian capitals).

Moreover, these "goods" can now be attributed a value-expressing price by exercise of money-demand in a comparative market system of aggregate individual preferences. $^{31}$ This fact implies that sight may be lost altogether of their other axiological dimensions, for their economic value is now forcefully on the foreground, not their religious sacredness, incomparable beauty, categorical moral normativity, vital ecological function, etc. As former Chief Economist of the World Bank Lawrence Summers stated: "the economic logic behind dumping a load of toxic waste in the lowest wage country is impeccable, and we should face up to that" (as cited in Smith, 2007). ${ }^{32}$

This conceptually confused yet "impeccable" logic explains why life-enabling economic, social, and cultural rights, irreducible to money-value have been repeatedly sacrificed to the pursuit of life-impairing economic efficiency, as amply testified $^{33}$ by, e.g.: longer working hours (Bunting, 2004; ICESCR, 1966, article 7(d)); less-inclusive pension schemes (Elliott \& Atkinson, 2008; ICESCR, 1966, article 9); reduced parental leave (Law 173/2008, article 7; Law 70/2009, article 18; ICESCR, 1966, article 10); cheaper, lower-quality school meals ("Allarme mense," 2008; ICESCR, 1966, article 11(1) and 12); reduced healthcare provision (Stuckler, King, and Basu, 2008; ICESCR, 1966, article 12); ${ }^{34}$ increased market opportunities for performance-enhancing drug-dealing, whether legal or illegal (Angell, 2004; D'Argenio, 2008; ICESCR, 1966, article 12); ${ }^{35}$ cuts to educational services

Studies in Social Justice, Volume 5, Issue 1, 2011 
(McMurtry, 1998; ICESCR, 1966, articles 13 and 14); and reductions in publicly funded cultural programs ("Budget cuts,” 2008; ICESCR, 1966, article 15).

Similarly, since at least the late 1970s, when it comes to determining the course of monetary policy in free-market economies, their sovereign right to issue coin and credit, and the levels of taxation for capital gains, there seems to have been no other guideline but to make entire countries "attractive" to business. ${ }^{36}$ This attractiveness has been so interpreted as to be achieved by slashing protective regulation, thereby maximising returns for private shareholders, even if entire societies are harmed in the process (Glyn, 2006; McMurtry, 1999; Stiglitz, 2003) and democratic self-rule is thwarted by oligarchic privilege. ${ }^{37}$ Indeed, the conflict between genuine political autonomy and large concentrations of wealth is as old as the very first modern democracy (Jefferson, 1816, 1817) and it has been described most adamantly by W.L. MacKenzie King former Prime Minister of Canada (COMER, 1996, p. 16): "Until control of the issue of currency and credit is restored to government and recognized as its most conspicuous and sacred responsibility, all talk of the sovereignty of Parliament and of democracy is idle and futile... Once a nation parts with control of its credit, it matters not who makes the nation's laws... Usury once in control will wreck any nation.”

The inherent conceptual confusion and absence of decisive life-criteria within the economic logic epitomized in Sumners' quotation can explain why so much contention has surfaced amid experts about whether the results of the long wave of privatizations of the 1980s-2000s have been socially positive or negative (e.g. Florio, 2004). As regards more specifically the privatization of credit creation and its unregulated free movement across borders, even influential conservative European statesmen seem to have no doubt any longer that it has been harmful, rather than beneficial, to collective wellbeing (e.g. Putin, 2009; Sarkozy, 2010; Tremonti as cited in Cazzullo, 2009). ${ }^{38}$ This fact becomes most evident if life-grounded nutritional standards and death rates are taken as relevant indicators of collective wellbeing, as done by spokespersons of one of the most active promoters of 1980s2000s financial liberalizations, i.e. the International Monetary Fund ([IMF] Plant, 2008; Strauss-Kahn as cited in Swann, 2008). ${ }^{39}$

As epitomized by Bill Clinton's presidency of the United States of America, privatizing services and productive structures that had been previously held by public bodies and delivering them into worldwide free trade was claimed to better serve human communities by promoting "growth," "development" and, as implied by analogous watchwords, much of what is desirable and good. ${ }^{40}$ Such has been the "conventional wisdom" of the past few decades, despite the equally obvious problems that profit-oriented activities posited vis-à-vis, to name one critical area, environmental safety. ${ }^{41}$ Indeed, as leading Finnish jurist Aulis Aarnio (1991) observed back then: "Environmental values and economic values often clash, as in the protection of the forests and waterways. Almost without exception, the values that have prevailed have been economic” (p. 131).

\section{The Current Crisis, the Life-Ground, and the ICESCR}

Twenty years later, the IMF acknowledges that "[t]he world economy is entering a major downturn in the biggest financial crisis since the 1930" ("Major Global 
Downturn," 2008) and the UN's Secretary-General states that the "economic and financial turmoil sweeping the globe is a true wake-up call, sounding an alarm about the need to improve upon old patterns of growth and make a transition to a new era of greener, cleaner development” (Ban, 2009).

Under these momentous and dramatic circumstances, McMurtry's substantial and objective theory of value, which treats life as the paramount end of human agency and economic activity as a means, becomes a plausible conceptual tool for reconsidering the axiological hierarchies that have led the international community to the crisis denounced by the UN's Secretary-General. Indeed, if one considers that McMurtry's main works focussed already in the 1990s on the pernicious axiological confusion of de-regulated financial activity in the face of persistent socio-economic meltdowns and environmental losses, their relevance as the current crisis is concerned is manifest and Cassandra-like. ${ }^{42}$

Under the same circumstances, the ICESCR becomes a major point of reference vis-à-vis the sort of value-choices that should be made so as to guide policy-making and international cooperation. First of all, the rights addressed by the ICESCR are precisely the sort of rights that today's crisis affects most critically. In times of crisis, it becomes more difficult for people to realize their own needs, fulfil their own rights, without state intervention; yet the state is simultaneously under pressure to cut such assistance, both domestically and internationally. Both scientific journals and mainstream media sources-the latter being generally more cautious vis-à-vis the economic powerhouses from which they directly or indirectly depend-have been revealing amply and candidly the astounding social, economic, and cultural losses due to the economic crisis since $2008 .^{43}$

Secondly, as discussed in Part 4, the ICESCR addresses economic, social, and cultural rights from a position that is ostensibly neutral as to a state party's economic system, at least up to a certain extent. ${ }^{44}$ As such, the ICESCR endures as a set of binding goals for the international community regardless of the dominant market ideology within a state and irrespective of whether the crisis incites more or less intervention. In fact, the ESCR Committee has pointed out that in times of economic crisis, the treaty becomes more, not less important: "under such circumstances, endeavours to protect the most basic economic, social, and cultural rights become more, rather than less, urgent” (General Comment No. 2, 1990, para. 9). ${ }^{45}$

Thirdly, of 192 member states of the UN, 160 are parties to the ICESCR and a further six have signed it. ${ }^{46}$ The state parties include states from all different geographical, legal, economic, cultural, and religious traditions at all levels of development, indicating shared recognition of the importance of economic, social, and cultural rights. Emblematically, after decades of negotiation, the Optional Protocol (OP-ICESCR, 2008) was unanimously adopted by the UN General Assembly in December 2008-just as World leaders were waking up to the depth of the current financial crisis. When opened for signature in September 2009, twentynine states immediately signed the protocol, indicating their support for the communications process. Since then and at the time of writing, a further four states have signed and two states have ratified it. ${ }^{47}$

Fourthly, and crucially for the aims of the present work, the ICESCR embodies paramount life-goals, consistent with McMurtry's understanding of value. The lifegrounded character of the ICESCR is manifest already in its preamble in which the

Studies in Social Justice, Volume 5, Issue 1, 2011 
vital dimensions of felt being and action are acknowledged as the goal to strive for: "the ideal of free human beings enjoying freedom from fear or want" (emphasis added). ${ }^{48}$ Each state is required to ensure the conditions that allow for moving in this direction, in other words "to take steps, individually and through international assistance and co-operation, especially economic and technical, to the maximum of its available resources, with a view to achieving progressively the full realization of the rights" (ICESCR, 1966, article 2(1)). No "freedom, justice and peace" can be attained if states fail in this task. To secure this fulfilment is not charity (ICESCR, 1966, Preamble); it is not an option; and it is not an expression of good will: it is a duty of states. So crucial are these rights, that even individuals are said to be morally bound by them: not as charity, not as an option, not as an expression of good will, but as a moral duty to their fellow citizens: "The State Parties to the present Covenant... realiz[e] that the individual, having duties to other individuals and to the community to which he belongs, is under a responsibility to strive for the promotion and observance of the rights recognized in the present Covenant" (ICESCR, 1966, Preamble). ${ }^{49}$

Strengthening the life-centred tone of the covenant, article 1 affirms that "[i]n no case may a people be deprived of its own means of subsistence.” Article 7 speaks of "just and favourable conditions of work... A decent living for themselves and their families... Safe and healthy working conditions... Rest, leisure and reasonable limitation of working hours and periodic holidays with pay." Article 8 requires "the right of everyone to form trade unions and join the trade union of his choice," given their historical role in promoting equitable access to life-goods under democratic regimes (e.g. Noonan, 2006). Article 9 recognizes "the right of everyone to social security, including social insurance." Article 10 acknowledges "[t]he widest possible protection and assistance... to the family... mothers... all children and young persons... [who] should be protected from economic and social exploitation... [e.g.] employment in work harmful to their morals or health or dangerous to life or likely to hamper their normal development." Article 11 identifies "adequate food, clothing and housing" as well as freedom "from hunger" and "an equitable distribution of world food supplies in relation to need" as key-factors in adhering to the covenant. Article 12 adds "physical and mental health... the reduction of the stillbirth-rate and of infant mortality... environmental and industrial hygiene... medical attention in the event of sickness." Articles 13 and 14 further acknowledge the thinking dimension of life by stressing "the right of everyone to education... Primary education... [to be made, if not already so,] compulsory and free to all," whilst "[s]econdary" and "[h]igher education" should "be made generally available and accessible to all." Similarly, article 15 highlights "the right of everyone... To take part in cultural life... enjoy the benefits of scientific progress and its applications... the conservation, the development and the diffusion of science and culture.”

Labour standards, nutritional standards, health and safety regulations, living standards, education, healthcare provision, the promotion and diffusion of cultural activities and scientific knowledge: they all spring from the life-ground and, unsurprisingly, they are recognized as valuable by the international community. McMurtry himself (2010) emphasizes the pivotal role that the rights enshrined in the ICESCR should play in rebuilding the life-fabric of "meltdown-ed" societies, "because of their centrality to contemporary human life and their bridging across the received disjunction between economic and ethico-political rights in an integrated 
shape.” As a matter of fact, the onto-axiology of McMurtry (2010) allows us to perceive that "the unifying principle of these rights is to protect and enable human life," which encompasses action (e.g. means of subsistence), felt being (e.g. mental health) and thought (e.g. education). A counterfactual test may suffice to further substantiate this point: none of these rights can be sensibly described as intentionally, eminently or evidently prone to biocide or life-destructive agency, at least as long as McMurtry's work is adopted as a viable philosophical hermeneutic, that is, a creative, insightful, learned, and rigorous set of wide- and deep-reaching categories of interpretation of reality.

\section{Fulfilling One's Duties, the Life-Ground, and the ICSECR}

The ICESCR appears to be a case of "civil commons." On the one hand, the rights addressed by the ICESCR are a conceptualization of the "commons" upon which human communities stand and, possibly, flourish, e.g.: the short- and medium-term life-sustaining means that all members need (articles 1 and 11); the protection and generation of human life (article 12); its adequate care, socialization and education (articles 10, 13 and 14); the long-term life-sustaining and life-enriching occupational, vocational and recreational opportunities of the physically and mentally fit members (articles 6, 7, 8 and 15); the humane and humanity-enhancing assistance due to those who are not fit (articles 9 and 12). On the other hand, the vast institutional consensus underpinning the ICESCR as a binding legal document requiring its parties to report regularly on the implementation of the covenant manifests that these commons are "civil" in the sense that they allow for civilization to be and continue to be (articles 16 and 17).

The ICESCR shows vividly how the international community already possesses long-standing resources for interpreting and resolving life-threatening circumstances, despite the fact that even a legally binding international human rights treaty is difficult to enforce. One means of evaluating firm obligations and adjudicating violations is to set a minimum level below which the citizens of all nations should never be allowed to fall, which is what the ESCR Committee has defined as "minimum core" obligations (General Comment No. 3, 1990, para. 10; Langford \& King, 2009; Chapman \& Russell, 2002). In this respect, McMurtry's understanding of human needs can serve as an example of where exactly one should set the threshold of the minimum core, at least as actual living persons-as distinguished from legal persons-are concerned. Progressive realization of the ICESCR ought to be pursued without drastic short-term sacrifices that undermine the most rudimentary means of life in the present. A failure to guarantee the minimum core, the fundamental organic capacity of each person in a state's jurisdiction, constitutes a violation of the covenant unless the state can demonstrate "that every effort has been made to use all resources that are at its disposition in an effort to satisfy, as a matter of priority, those minimum obligations” (General Comment No. 3, 1990, para. 10).

The reduction of organic capacity can take many forms, be more or less expedite, and more or less rapidly fatal. Death is its most easily detectable indication, and it is in fact mentioned in the ICESCR itself (e.g. article 12). Still, it is possible to observe reduction of organic capacity long before that final stage, which is what the ICESCR

Studies in Social Justice, Volume 5, Issue 1, 2011 
presumes by its references, inter alia, to "the fundamental right of everyone to be free from hunger" (article 11(1)), and "the prevention, treatment and control of epidemic, endemic and occupational diseases" (article 12(2)(c)). Social scientists tracking rates of spousal abuses, nutritionists and social workers monitoring nutritional imbalances and poverty, public health experts reporting on pathological trends and their causes, whether aware of the covenant or not, are all engaged in a worldwide assessment of life-grounded phenomena that are pertinent to the aims of the ICESCR. ${ }^{50}$

As concerns the variety of ways in which reduction of organic capacity can happen, scientific standards are debatable and debated, as all human creations are, but are nevertheless employed daily by national public bodies and international authorities in determining, for example, the acceptable quality level of school meals (e.g. 1981 United States Department of Agriculture [USDA] discussions on whether to assess ketchup as a vegetable), the new types of car engines that may be manufactured and sold (e.g. European-Union[EU]-wide emission standards), plausible grounds for separation or divorce (e.g. German judges' use of expert psychiatric opinions), literacy requirements for job applicants (e.g. British literacy and numeracy tests for aspiring civil servants), the regularity and fairness of democratic elections (e.g. regular monitoring of elections worldwide by the Organisation for Economic Cooperation and Development [OECD]). Consistently, the ESCR Committee requires states parties to submit detailed and disaggregated sociological data in its initial and periodic reports in order to review each state's situation in light of its obligations (State Report Guidelines, 2009). ${ }^{51}$

In this connection, McMurtry (2002) offers a "Well-Being Index" (WBI) comprising "the complete and universal set of needs which all humans require to be met in order to flourish" (p. 156). This re-grounding of standard scientific and institutional criteria and praxes as civil commons includes:

1. breathable air, sense-open space, and daily light (atmospheric means of life)

2. clean water, nourishing foods and self-waste disposal (bodily means of life)

3. shelter space from the elements with ample provision to retire, sleep and function (home means of life)

4. environmental surroundings whose elements and contours contribute to the whole (environmental means of life)

5. intimate love, social inclusion, safety and healthcare when ill or infirm (caring means of life)

6. activities of language-logos/art-play to choose and learn from (educational/recreational means of life)

7. meaningful work or service to perform (vocational means of life)

8. self-governing choice in each's enjoyment consistent with each's provision (just form of life)

Debatable and perfectible-McMurtry himself has produced different versions of it - the WBI highlights several needs without meeting which human life, both individual and collective, would eventually disintegrate by accumulated physical and mental deficiencies. ${ }^{52}$ The WBI has a willing accomplice in the ESCR Committee's 2001 statement on poverty, in which the Committee attempts to integrate human 
rights in poverty eradication strategies. The statement addresses poverty in the following terms:

\begin{abstract}
In the recent past, poverty was often defined as insufficient income to buy a minimum basket of goods and services. Today, the term is usually understood more broadly as the lack of basic capabilities to live in dignity. This definition recognizes poverty's broader features, such as hunger, poor education, discrimination, vulnerability, and social exclusion. The Committee notes that this understanding of poverty corresponds with numerous provisions of the Covenant. In the light of the International Bill of Rights, poverty may be defined as a human condition characterized by sustained or chronic deprivation of the resources, capabilities, choices, security and power necessary for the enjoyment of an adequate standard of living and other civil, cultural, economic, political and social rights (ESCR Committee, 2001 para.. 7-8).
\end{abstract}

Considering the WBI in light of the ICESCR and the work of the Committee, we can compare as follows:

1. atmospheric means of life:

The ICESCR incorporates "the right of everyone to the enjoyment of the highest attainable standard of physical and mental health" (article 12(1)) and imparts a duty on states to take steps towards the "improvement of all aspects of environmental and industrial hygiene" (article 12(2)(b)) and ensure a "[s]afe and healthy working environment" (article 7(b)). The ESCR Committee recognizes "a healthy environment" as a fundamental component of the right to health (General Comment No. 14, 2000, para. 4 and 15).

\title{
2. bodily means of life:
}

"The States Parties to the present Covenant recognize the right of everyone to an adequate standard of living for himself and his family, including adequate food, clothing, and housing, and to the continuous improvement of living conditions” (ICESCR, 1966, article 11(1)). Identified minimum core rights include the right not to be hungry and to have access to nutritionally and culturally adequate food and a safe water supply covering essential needs, with non-discriminatory, genuine and safe access to and equitable distribution of water facilities (General Comment No. 12, 1999, para. 8; General Comment No. 14, 2000, para. 43(b)(c); General Comment No. 15, 2002, para. 37). The state parties "recogniz[e]... the essential importance of international cooperation based on free consent” (ICESCR, 1966, article 11(1)). With regard to the right to be free from hunger (as distinguished from the right to adequate food), state parties "recognizing the right of everyone to be free from hunger, shall take, individually and through international cooperation, the measures, including specific programmes, which are needed:" to improve food production, conservation and distribution and ensure an "equitable distribution" of food supplies (article $11(2))^{53}$

Studies in Social Justice, Volume 5, Issue 1, 2011 


\section{3. home means of life:}

This is incorporated in article 11 above and has a dedicated general comment (General Comment No. 4, 1991). Additionally, "[b]asic shelter, housing and sanitation" are recognized as minimum core components of the right to health (General Comment No. 14, 2000, para. 43(c)). The right to social security crosses both bodily and home means of life, including, as the minimum core, that each have access to social security providing a "survival standard" (General Comment No. 19, 2007, para. 59).

\section{4. environmental means of life:}

The ICESCR has a limited approach to the environment, recognizing its value only where it contributes to the realization of "human" rights. This point will be addressed in greater depth below (Part 7).

\section{5. caring means of life:}

"The widest possible protection and assistance should be accorded to the family, which is the natural and fundamental group unit of society, particularly for its establishment and while it is responsible for the care and education of dependent children... Special protection should be accorded to mothers during a reasonable period before and after childbirth" (ICESCR, 1966, article 10). The ESCR Committee has highlighted the importance of family for persons with disabilities and older persons, groups whose members have historically found their rights to live in a supportive family environment constrained (General Comment No. 5, 1994, para. 30-32; General Comment No. 6, 1995, para. 31). The Committee has a dedicated general comment on the right to health in which they identify the minimum core components of health-care, including non-discriminatory access to and equitable distribution of health-care services and essential drugs (General Comment No. 14, 2000, para. 43(a) and (e)).

\section{6. educational/recreational means of life:}

States parties "recognize the right of everyone to education" (ICESCR, 1966, article 13(1)). This right is not only the right of children to schooling but to all individuals of all ages to education at a suitable level. The minimum core incorporates basic primary education and equality of access to all for education at other levels (General Comment No. 13, 1999, para. 57). Primary education must be "compulsory and available free to all" (implicitly including adults who lack basic numeracy and literacy skills; ICESCR, 1966, article 13(2)(a)) and this is the only provision for which the means for progressive realization are spelt out in a distinct ICESCR article, which requires:

Each State Party to the present Covenant which, at the time of becoming a Party, has not been able to secure in its metropolitan territory or other territories under its jurisdiction compulsory primary education, free of charge, undertakes, within two years, to work out and adopt a detailed plan of action for the progressive implementation, within a reasonable 
number of years, to be fixed in the plan, of the principle of compulsory education free of charge for all (article 14).

The minimum core of the right to "take part in cultural activities" (article 15) includes non-discriminatory access, free expression and choice as to whether to participate in cultural activities, and involvement of stakeholders in development of policies relating to cultural activities (General Comment No. 21, 2009, para. 50). Further, states recognize, within the context of the right to work, the right of everyone to " $[\mathrm{r}] \mathrm{est}$, leisure and reasonable limitation of working hours and periodic holidays with pay, as well as remuneration for public holidays” (ICESCR, 1966, article $7(d))$.

\section{7. vocational means of life:}

The ICESCR states that "the States Parties to the present Covenant recognize the right to work, which includes the right of everyone to the opportunity to gain his living by work which he freely chooses or accepts, and will take appropriate steps to safeguard this right" (article 6(1)) and they "recognize the right of everyone to the enjoyment of just and favourable conditions of work" (article 7). Within the minimum core of the right to work are the fundamental principles of equal access to employment and non-discrimination (General Comment No. 18, 2005, para. 31).

\section{8. just forms of life:}

The indivisibility of the ICESCR and the ICCPR means that fundamental freedoms may not be sacrificed in order to fulfil basic needs or economic, social, and cultural right (ICESCR, 1966, Preamble; General Comment No. 3, 1990, para. 6 and 8). Thus, for example, is individual self-determination recognized as a central element of the right to health and coercive medical treatment is prohibited (General Comment No. 14, 2000, para. 34).

In line with McMurtry's theory of value, rights are established by the ICESCR so that needs are met and life thus enabled to open towards wider ranges of: ${ }^{54}$

(a) action, e.g. stepping from sheer survival (the right not to be hungry as the minimum core) to adequate food, i.e. a nutritious, well-balanced diet (full realization of the right to food);

(b) felt being, e.g. stepping from adequate food to adequate good food (food can possess an aesthetic dimension that encompasses several different levels of sentience); and

(c) thought, e.g. stepping from adequate good food to adequate, good, culturally significant food (traditions and local culture can be expressed and apprehended via food choices and food-related rituals). ${ }^{55}$

The ICESCR was not promulgated in order to specify only a floor below which nations may not fall. Rather, it was meant to provide its parties with defining principles and purposes concerning the sort of development desired by the international community. The "minimum core" obligations are merely a starting

Studies in Social Justice, Volume 5, Issue 1, 2011 
point. The distance from which each country still stands from fulfilling the covenant over 30 years after its entry into force, and, indeed, the regressive outcomes in a number of states, suggest that new conceptions of the factors that systematically oppose the ICESCR are needed. ${ }^{56}$ The time may have come for McMurtry's axiology to enter into the human rights mainstream.

\section{The Environment, the Life-Ground, and the ICSECR}

McMurtry's WBI is his most conspicuous contribution to the alternative standards for the measurement of growth and wellbeing (e.g. Human Development Index [HDI], Genuine Progress Indicator [GPI], the Statistics Canada System of Environmental and Resource Accounts) that have been championed in the recent past by a number of scholars and scientists, such as Amartya Sen (1992) and Gene Shackman (2006-9). ${ }^{57}$ Some such alternative standards have already been used by the UN and other institutions, including the World Bank, in order to deal with the dimensions of human capital and natural capital and, more generally, to attempt to assess growth and decline in non-market-dependent ways. ${ }^{58}$ Nevertheless, they are still far from being the leading parameters of evaluation actually employed by individual states and major international organizations vis-à-vis economic performance and inform most decisive aspects of policy-making (Latouche, 2004, 2007). Almost without exception, what has appeared to be paramount to states in the end is growth or potential for economic growth, narrowly defined by life-blind money-value parameters, whilst human rights considerations have been left largely undersupplied (McMurtry, 2002, 2009-10).

Were growth measured in this sense to correspond with progressive realization of economic, social, and cultural rights, then the bare pursuit of growth would be a reasonable interpretation of the most "appropriate means" for a state to take to fulfil the Covenant. Yet, as highlighted by the current crisis, this does not seem to be the case (e.g. UN, 2002-9 and Ban, 2009). ${ }^{59}$ In particular, what has emerged from expert debates on the destabilization of climate and hydrological cycles is that the type of growth pursued under the banners of "globalization" and "international trade" has had systemic negative implications upon both human health and the environmental conditions of planetary survival. That is to say, "globalization" and "international trade" have had systemic negative implications upon the integrity of life support systems at all levels, thus affecting the possibility of satisfying vital needs through generational time (UN, 2002-10; Worldwatch Institute, 2009).

As we write, the deepest "living conditions" of humankind, present and future, are being impoverished to an unprecedented rate. The international scientific community at its highest and most representative levels has denounced vocally and repeatedly that human civilization has become for the first time in its history a threat to the planetary environment that allows for humanity's own existence (Union of Concerned Scientists, 1997). Eminent scholars have further emphasized this point. A few weeks before his death, Hans Jonas (1993), father to modern bioethics, declared in a speech (translation by the authors):

[E]very debate about race has become anachronistic, irrelevant, almost farcical vis-à-vis the gigantic challenge that our threatened environment 
throws in the face of the entire humankind. Caught in the grip of this challenge, whether it knows it or not, humankind becomes one kind, as it loots its earthly home, shares the fate of its own ruin, and remains the only possible saviour of both: the Earth and itself... [T]he "human condition" has been transforming... In the old days religion told us that we were all sinners because of the original sin. Today it is our planet's ecology that accuses all of us of being sinners because of the overexploitation of human ingenuity. Back in the old days religion terrified us with the Last Judgment at the end of times. Today our tortured planet predicts the coming of that day without any divine intervention. The final revelation... is the silent scream emerging from things themselves, those things that we must endeavour to resolve to rein in our powers over the world, or we shall die on this desolate earth which used to be the creation. ${ }^{60}$

These words may seem rhetorically blown out of proportion, but heed should be paid to the fact that there is actually no aspect whatsoever of the Earth's environment that has not been depleted in the processes of extraction, production, transportation, consumption, and disposal of the "goods" enhancing today's mainstream conception of "growth": the biosphere-protecting ozone layer, breathable-air producing and reproducing pluvial forests and oceanic life-systems, vegetal- and animal-lifesupporting hydrologic cycles, self-regenerating water aquifers, nourishing-foodproducing arable spaces, and natural-equilibrium-maintaining and science- and technology-inspiring biodiversity (UN, 2002-10). Denials of this dramatic situation are an exercise in intellectual dishonesty, as the causal link between the pursuit of profit in contemporary market economies and environmental degradation becomes visible every time environmental and health-and-safety regulation, or effective enforcement thereof, is resisted as "too costly," "rigidifying" or "anti-competitive" (Gaggi, 2008; International Labour Organisation, 2006), or is by-passed by illicit behaviour and/or by off-sourcing to countries that have actually little such regulation or none at all. ${ }^{61}$

McMurtry's serving as Honorary Theme Editor for the philosophy section of UNESCO's EOLSS highlights the fact that one of the recurring concerns of his oeuvre is the acknowledgment that a healthy biosphere is valuable as such. By contrast, the ICESCR does not address environmental concerns for their own sake. For that reason, the ESCR Committee cannot make broad statements of law or policy on environmental issues but can only address the environment from a strict anthropocentric perspective. In other words, under the ICESCR, the environment has no intrinsic value, but is only valuable to the extent that it maintains or improves humans' abilities to enjoy their economic, social, and cultural rights. As a result, the Committee has no self-standing general comment on the environment or the need for the development required to fulfil economic, social, and cultural rights to be "sustainable." Nevertheless, the perpetual validity of the ICESCR implies that immediate moves to fulfil its provisions must not come at the cost of future fulfilment. ${ }^{62}$ Thus, the Committee recognizes both the relevance of the environment for current enjoyment of human rights as well as the need for sustainability in the means chosen to realize human rights. ${ }^{63}$

A "healthy environment" is an integral factor in realising the highest attainable standard of health and explicitly addresses states' responsibilities to reduce

Studies in Social Justice, Volume 5, Issue 1, 2011 
workplace toxins that threaten the health of either employees or the general population (General Comment No. 14, 2000, para. 4, 11 and 15). The right to water requires control of pollutants and additional protection in times of crises, such as conflict or natural disasters (General Comment No. 15, 2002, para. 7 and 22). The Committee adopts "respect for the environment" as one of the aims of education, with reference to the World Declaration on Education for All, and considers it "implicit in, and reflect[ing] a contemporary interpretation of article 13(1)" (General Comment No. 13, 1999, para. 5).

Sustainability was addressed by the ESCR Committee in 1991 in the general comment on the right to adequate housing which requires "sustainable access to natural and common resources, safe drinking water, energy for cooking, heating and light, sanitation and washing facilities, means of food storage, refuse disposal, site drainage and emergency services” (General Comment No. 4, 1991, para. 8(b)). The concept came into its own in the context of the right to food when the Committee asserted that adequacy and sustainability are two sides of the same coin: "The notion of sustainability is intrinsically linked to the notion of adequate food or food security, implying food being accessible for both present and future generations” (General Comment No. 12, 1999, para. 7). The sustainability of food resources is considered to be so fundamental as to constitute an element of the minimum core of the right to adequate food (General Comment No. 12, 1999, para. 8). On the same basis, sustainability is a crucial component of the right to water (General Comment No. 15, 2002, para. 11).

These comments are particularly relevant for contemporary capitalist countries, the number of which has grown tremendously since the disappearance of Europe's Communist bloc. From a life-grounded standpoint, for example, a global free market that still causes scores of diseases due to pollutants, junk food, and addictive substances, (Boffetta, 2006; World Health Organization [WHO], 2009) while corporate pharmaceutical profits boom, (Angell, 2004) is not a desirable development model for it implies that such a market has been interested inherently in perpetuating or worsening such pathological circumstances rather than preventing them (Clorfene-Casten, 1996). On a global scale, as Hans Jonas’ remarks anticipated, "growth" in the orthodox economic sense may have even been pursued successfully for the past two decades (Shackman, 2007), the ongoing international crisis notwithstanding. Yet, at the same, this narrowly conceived growth has been reducing the likelihood of planetary survival via depletion of the Earth's life support systems and the ability of states and the individuals within them to realize their economic, social, and cultural rights (UN, 2002-10). ${ }^{64}$

\section{Concluding Remarks}

Lawrence Summers' “impeccable” logic stands today under-reformed, if not unreformed, within the legal frameworks and the concrete policies of nearly all countries suffering from the ongoing economic crisis. ${ }^{65}$ On the contrary, states have rescued and revived profit-driven banks that were responsible for the crisis with public money, which is not being used to fund life-protecting and life-enhancing institutions. Quite the opposite, public expenditures are being reduced most thoroughly in several countries so as to counter the risk of inflation, which is 
demonstrated thereby to be a much more pressing concern to many governments, economists and business elites than environmental degradation and the fulfilment of the rights enshrined in the ICESCR. ${ }^{66}$

Such money-centeredness and life-blindness do not come as a surprise, for the lifedestructive expressions of today's leading economic system have been not aberrations, but recurrent, ordinary aspects of the same. ${ }^{67}$ They are the result of a faulty understanding of value, which does not consider the long-term satisfaction of vital needs as paramount, and focuses instead upon for-profit "short-termism" (Baruchello \& Lintner, 2009, p. 40). Laconically, McMurtry (1999) connotes this faulty understanding of value as follows: "The system is by its inner logic a horizonlessly expanding money-demand machine engineering all that lives to extract more money value from it, to reduce the costs of continuing its existence, or to extinguish it as of no money worth" (p. 242). ${ }^{68}$

In this system, value has been shown daily and repeatedly not to correspond to the life-grounded parameters enshrined in the ICESCR, but rather reduced to the money price that one can get for whatever alleged "good" may be traded in a money-based market of buyers and sellers, such that each of them seeks only, or is expected to seek only qua rational agent, the most for herself (Castoriadis, 1997a). If the rights sanctioned in the ICESCR are ever to enjoy a brighter future, then many governments, economists and business elites will have to prove themselves capable of undergoing a major value shift, which is what McMurtry's axiology has been offering for some time.

\section{Notes}

1 For the sake of avoiding repetition, "theory of value" and "axiology" are used as synonyms. In contrast, McMurtry's "life-grounded onto-axiology" is going to be explained and discussed in detail. Although still alive and active, John McMurtry has already produced a significant amount of literature in axiology, which can therefore be considered established as a coherent set of conceptions.

2 The number of researchers making use of this original notion has been growing steadily for at least a decade (e.g. Ato, 2006; Dickinson, Becerra, \& Lewis, 2009; Finlay, 2000; Florby, Shackleton, \& Suhonen, 2009; Hodgson, 2001; Johnston, 2003; Johnston, Gismondi, \& Goodman, 2006; Jordan, 2004b; Kaara, 2005; Mook and Sumner, 2008; Noonan, 2006; Scarfe, 2006; Shurville \& Brown, 2009; Shurville, Brown, and Whitaker, 2009; Streeck, 2009; Turner \& Brownhill, 2004; Westhues, 1999).

3 As of 2003 John McMurtry has been the Honorary Theme Editor for the philosophical section of EOLSS, i.e. the world's largest repository of information on sustainable development and related issues or, as defined by the UN, on "life support systems" i.e. "[A]ny natural or humanengineered (constructed or made) system that furthers the life of the biosphere in a sustainable fashion. The fundamental attribute of life support systems is that together they provide all of the sustainable needs required for continuance of life. These needs go far beyond biological requirements. Thus life support systems encompass natural environmental systems as well as ancillary social systems required to foster societal harmony, safety, nutrition, medical care, economic standards, and the development of new technology. The one common thread in all of these systems is that they operate in partnership with the conservation of global natural resources" (UN, 2002-10, "Definitions,” para. 2).

4 There were 48 positive votes and 8 abstentions.

Studies in Social Justice, Volume 5, Issue 1, 2011 
5 Cf. ICESCR, 1966, article 2(1) and ICCPR, 1966, article 2; article 23 applies a "progressive realization" standard vis-á-vis equality in marriage since states did not consider themselves able to immediately guarantee this right. This is not to suggest that even in 2011 states are successful in fulfilling the ICCPR in its entirety.

6 In July 2010, OP-ICESCR had attracted 31 signatures and 2 ratifications. On coming into force, it will have a competence comparable to that of the Human Rights Committee to consider communications from aggrieved individuals or groups. Noteworthy are also the General Comments by the ESCR Committee, 1989-2009, and the concluding observations on state reports, included in the committee's annual reports to the Economic and Social Council (ECOSOC).

7 Curiously, South Africa is not a party to the ICESCR, having signed in 1994 but never ratified, yet its constitution reflects much of its content, even using the Committee's framework of duties to respect, protect and fulfil human rights (Constitution of the Republic of South Africa, 1996, s7(2); see also Liebenberg, 2009). Other countries that incorporated economic, social, and cultural rights in recent constitutions include: Brazil, Bulgaria, Burkino Faso, Congo, Colombia, Estonia, Hungary, Macedonia, Poland, and Turkey (cf. Langford, 2009, footnote 39 and this collection in general for reviews of over 2000 cases).

8 For a review of the debate, see Nolan, Porter, and Langford (2007). The debate has moved on from whether economic, social and economic rights are justiciable to how they can best be adjudicated (p. 29).

9 Harvard professor Ralph Barton Perry (1954) argued: "a thing-anything-has value or is valuable in the original and generic sense, when it is the object of interest-any interest" (pp. 23). Nicholas Rescher (1969), "champion" of the Anglo-American analytic tradition, rarefied further the notion of value and reduced it to the status of linguistic rationalization of individual yens: "A value represents a slogan capable of providing for the rationalization of action by encapsulating a positive attitude toward a purportedly beneficial state of affairs" (p. 9). Even more abstract was Zdzislaw Nadjer's (1975) option, whereby: " $M$ is an axiological value if and only if $\mathrm{M}$ is a judgement, ascribing the quality of valuableness to objects, properties or states of affairs, and constituting within the given value-system a final justification of other judgements of the system” (pp. 63-4).

${ }^{10}$ Michel Foucault (2008) claims that the prolonged experience of top-down determination of social values by the state, from "Bismark's state socialism" to "National Socialism” (p. 101), was a crucial factor in the development of German neo-liberalism, most notably Hayek's work its emphasis upon individual independence in value options by way of the principle of free choice in the free market.

11 McMurtry (2009-10) characterizes his own theory of value as "onto-axiology," thus stressing the connection between value — as indicated by "axiology" — and being as such—as indicated by the prefix "onto-." The life-ground is therefore both (a) the vital platform of life support systems upon which all values stand as real-world beings, and (b) the prime value that all beings reveal, whether explicitly (e.g. McMurtry's own theory, the UN's EOLSS) or implicitly (e.g. by eating, seeking medical assistance, or preferring life to death).

${ }^{12}$ A considerable amount of philosophical and socio-political literature has centred in recent years upon "life," yet in connection with the Foucauldian notions of "biopower" and "biopolitics" (e.g. Agamben, 1998, 2005; Esposito, 2004, 2005). However, no attempt has been made to clearly define "life" and articulate it beyond the juxtaposition of "zoe" (biological life) and "bios" (political and/or fully human life), nor has any objective criterion of value been proposed in this context (Nacci, 2009).

${ }^{13}$ Limited attention has been paid by Western philosophers to the life-ground, which has been regularly presupposed or left under-analyzed (Allen \& Baruchello, 2007; Baruchello, 2007b). As a consequence, this essay is going to refer extensively to John McMurtry and McMurtry scholars.

14 To deny the life-ground's import constitutes a token of performative contradiction (Baruchello, 2009). Besides, even philosophical pessimism (Baruchello, 2005) and otherworldly religions have testified to it (Baruchello, 2007b).

15 Logically, it is possible to distinguish between life as possessing intrinsic value and the lifeground as being instrumentally valuable. Ontologically, this is impossible: "All that is of worth consists in and enables life value to the extent of its experienced fields of thought, felt being and action (intrinsic value), and what underlies and enables these fields of life themselves, life support systems" (McMurtry 2009-10, para. 6.1.4).

${ }^{16}$ After Maslow's (1943) pioneering work in the field, Rollo May (1969) was alone, in the late 1960s, in challenging Pareto's notion of ophelimity and suggesting that value is what satisfies a 


\section{Giorgio Baruchello \& Rachael Lorna Johnstone}

need, rather than a preference. Later, apart from McMurtry, few others have tackled "need" in depth, e.g. Jennifer Sumner $(2005,2008)$ and Jeff Noonan (2006) — who are McMurtry scholars like Giorgio Baruchello—-Len Doyal and Ian Gough (1991), David Wiggins (2002), and Julio Boltvinik (2007).

17 "Need" is hardly discussed and articulated in recent literature, to the point of being undistinguishable from the cognate notion of "preference" (or "desire," "want"), e.g. one of Italy's most used reference websites for students in economics and the social sciences recites: "Needs are a feeling of dissatisfaction due to the want of something. Human needs are unlimited, subjective, resurgent and variable" ("I bisogni," 2007). Yet, as argued by Jeff Noonan (2006) "needs" and "preferences" (or "desires," "wants") can be distinguished sharply from each other. First of all, "deprivation of needs always leads to harm whereas deprivation of wants is only harmful in light of revisable self-interpretation" (p. xiv). Secondly, "needs are satiable whereas wants are not” (p. 57).

18 To avoid misunderstandings, it should be emphasized that: (a) organisms can be harmed psychologically, not just physically; and (b) organisms are not always reducible to individual creatures. It is long-standing practice in the sciences to regard societies (e.g. Spencer, 1860; Steiner, 1985; Hodgson, 1993) and ecosystems (e.g. Bunyard, 1996; Lovelock, 1979) as being organisms comprising others within themselves.

19 There may be simpler and more complex comparisons of value or evaluations of life-gains and losses. Nevertheless, if McMurtry's axiology is correct, then the preferred option in hard cases should be still the result of comparisons of life-value, e.g. a court's painful decision to separate a child from her cruel parent to foster the former's "best interest," or John of Salisbury's and John Milton's classic justifications of tyrannicide.

${ }^{20}$ No ontological dualism is implied: "Although we can distinguish the cognitive and feeling capacities of any person, this does not mean dividing them into separate worlds as has occurred in the traditional divisions between mind and body, reason and the emotions. Life-value ontoaxiology begins from their unity as the nature of the human organism" (McMurtry, 2009-10, para. 6.3).

21 McMurtry's onto-axiology allows for the determination of good and evil, cutting across received dualisms (e.g. utilitarianism vs. deontology, free choice vs. paternalism, free trade vs. protectionism, individualism vs. collectivism, etc.). Life-enablement and disablement signal respectively positive progress and negative regress.

${ }^{22}$ Noonan (2006) argues that the history of democracy should be understood as the struggle of downtrodden sectors of society to attain guaranteed access to vital resources and pursue increased life-capability.

${ }^{23}$ In our use of "institution" as semiotic artefact we follow Castoriadis (1997b): "The social imaginary is not the creation of images in society, it is not the fact that one paints the walls of towns. A fundamental creation of the social imaginary, the gods or rules of behavior are neither visible nor even audible, but signifiable" (p. 183).

${ }^{24}$ Buried in historical contexts, the life-supporting character of the civil commons has been expressed in a variety of forms. The same applies to their management, e.g. religious precepts, laws, medical prognoses.

25 The "civil commons" embrace both social and natural commons, for the latter become social too as soon as they are conceived of as commons and regulated accordingly.

${ }^{26}$ George Soros (1998) and Joseph Stiglitz (2003) dub "market fundamentalists" those economists who, since the 1970s, have been proclaiming one interpretation of capitalism—known as "neoliberal" or "neoclassical"- to be absolutely good. Still, the dogmatic, if not outright political character of economics runs further back in the history of the discipline, as the Michigan Institute of Technology's economics visiting committee tried to have Paul Samuelson's 1948 classic textbook called off because of its inclusion of "left-wing” Keynesian economics (Poterba as cited in Krugman, 2010b).

${ }^{27}$ It follows that, were the privatized civil commons to fail a life-grounded test of success, alternatives ought to be sought promptly, e.g. nationalization of "too-big-to-fail" private companies, as discussed in Galbraith (1977).

${ }^{28}$ Unless explicitly and effectively prohibited by public authorities in their capacity as civil commons, the for-profit commerce of human beings or parts of their bodies is far from being a thing of the past, not only as a daily engagement for criminal organizations, but also as an acceptable notion amongst academics. Morrison and Wilhelm, jr. (2007) argue the outlawing of

Studies in Social Justice, Volume 5, Issue 1, 2011 
indentured servitude to be an example of how the state has historically "undermined an agent's property rights over his own person” (p. 43). On his part, Savulescu (2003) argues that "[p]overty which is acceptable to a society should not be a circumstance which prevents a person" from selling her organs; to prevent it by law exemplifies "paternalism in its worst form" (p. 193). Were ever the trade of human organs to be explained on life-grounded premises, still the fundamental question is begged here as to why the poverty that leads a person into selling no less than parts of her body should be accepted at all.

${ }^{29}$ In 2009 the World Bank criticized the Chinese government for not stimulating adequate domestic consumption (Rampini, 2009)—of whatever consumer goods, e.g. life-enabling rice and lifedestructive cigarettes.

${ }^{30}$ Ingerid Straume (2008) argues that the conceptual blindness to children of liberal and neo-liberal economics extends to traditional liberal political thought, which takes as its starting point the adult.

${ }^{31}$ This idea is often referred to as "consumer sovereignty," whereby some people, i.e. moneyed people, are willing to purchase certain priced goods rather than others, thereby steering their production and their price. In this manner, money-demand determines that one thing is more important than another (Galbraith, 2007).

32 Most examples of for-profit life-depletion discussed in this essay focus on the biological dimension of life, but the psychological dimension is commonly affected too, for entire sectors of today's economy thrive on promoting, preserving and managing human unhappiness (Galeano, 2000; Orbach, 2009).

33 Our use of references to mainstream media sources is meant to show how McMurtry's axiology allows for the comprehensive understanding of everyday phenomena that are treated typically as distinct.

34 Jordan (2004a) argues that free-market emphasis on individual choice has not only reduced the funds available to public services, but has also damaged their role as the collective context for convivial, co-operative social relations and the socially beneficial sense of widespread solidarity and civic community.

${ }^{35}$ Aside from outright crime (Public accountant, 2008; “Usa,” 2008), the border between legal and illegal profiteering is porous, insofar as illegal revenues are recycled in, and to the benefit of, legal ones.

${ }^{36}$ Hobsbawm (1995, 2000), Elliott and Atkinson (2008) argue that the advent of neo-liberalism in the 1970s meant the end of a thirty-year-long period of state-overseen, real-economy-centred, wealth-redistributing development, which was itself a Keynesian "compromise" aimed at preventing any illiberal, Soviet-like revolution from taking place in the West. In this view, neoliberalism has been staunchly counter-reformist.

37 Exceptions have not been absent altogether, such as China and, more recently, Malaysia, whose governments refused to follow wholeheartedly this agenda, despite pressure from the IMF and the World Bank (Basu, 2008; McMurtry, 1999). Still, meltdowns have been frequent worldwide, bearing high social and environmental costs.

${ }^{38}$ Many critical voices of the 1980s-2000s, including McMurtry's, were ridiculed and marginalized by growingly dogmatic economists and streamlined scholars, thus preparing the ground for today's crisis. Sneeringly, Foreign Affairs contributor Jagdish Bhagwati (2002) wrote: "The disappearance of alternative models of development provoked anguished reactions from the old anticapitalists of the postwar era... from socialists to revolutionaries... captive to a nostalgia for their vanished dreams... in fields other than economics. English, comparative literature, and sociology are all fertile breeding grounds for such dissent” (pp. 2-3).

${ }^{39}$ In the aftermath of the recent "credit crunch" crisis, the number of persons going hungry worldwide grew sharply as a consequence of the subsequent real-economy crisis that reduced commercial and employment opportunities for vast sectors of the population of many countries (Fao, 2008; Vidal, 2008). This latter and more life-destructive crisis is still unfolding, also in the affluent nations where the former crisis was initiated, as noted by respected commentators (e.g. Krugman, 2010a; Posner, 2010). This crisis adds also further havoc to the impacts of previous structural adjustment programmes and policies, which have been widely researched and critiqued in connection with the actual enjoyment of economic, social, and cultural rights (Narula, 2006). Countries with IMF-led structural adjustment programmes have been found to have worse food security, both relative to other similarly situated countries and to themselves prior to the IMF's intervention (e.g. Argentina; cf. Langford \& King, 2009). Having much stronger enforceability mechanisms than human rights treaties, the effect of some international financial restructuring 
agreements has been to divert state's attention from its obligations to its population and towards its agreements with international financial institutions (Narula, 2006). Besides, the loan conditions imposed by the IMF often make it less rather than more likely that the loan will ever be repaid (Narula, 2006). Indeed, the charters of such organizations as the IMF and the World Bank do not explicitly authorize them to take account of human rights matters when formulating and implementing restructuring programmes. Nor, being states, can they become parties to the ICESCR or any other human rights treaty, even if they so desired. On the other hand, to the extent to which certain human rights norms constitute customary international law and even ius cogens - such as the prohibition of slavery and apartheid-the permissible actions of these organizations may be prescribed (Belgium v Spain, 1970, para. 34; UN, 1945, article 55). Still, few, if any, provisions of the ICESCR can be considered to have reached the status of customary international law, therefore it may be more conducive to consider instead the responsibility of the member states of multi-state institutions, the vast majority of whom are parties to the ICESCR.

40 Democracy itself has been believed to follow from free trade: "Just as democracy helps make the world safe for commerce, commerce helps make the world safe for democracy. It's a two-way street” (Clinton, 1996, p. 36). Consistently, independent non-capitalist countries were targeted in secret since the 1980s for "quiet revolutions" aimed at bringing them free trade and Western-style democracy (e.g. Chossudovsky, 1996).

${ }^{41}$ We do not claim that public provision of services and public ownership may not be as environmentally damaging as their private counterparts, as amply demonstrated by the disastrous environmental record of former Soviet Union (Deutsch, Feschbach, \& Friendly Jr., 1968; Ziegler, 1990). Systemic arrangements may be necessary, albeit per se insufficient to secure lifeprotection and promotion: individual behaviour must also be consistent with systemic aims for these to be attained, partially or entirely.

42 McMurtry (1999) writes: "[F]inancial crises always follow from money-value delinked from real value, which has many names but no understanding of the principle at its deepest levels” (p. 243).

43 Starvation levels are still rising ("U.N.: One billion worldwide face starvation," 2009); unemployment soars around the developed World ("A decade of high unemployment is looming," 2009; Barkham, 2010; Seager \& Elliott, 2009; Weisbrot, 2010; Tremlet, 2010; Vinnumálastofnun, 2010); wages are cut (Traynor, 2009; McDonnell, 2009); and out-of-work social security rightspaid for by contributions during the boom years-are under attack (Elliott, 2010a); pensions are reduced (Traynor, 2009) ; mental pathologies are expected to take a heavier toll in coming years (Smith, 2008); nutritional standards have been dwindling and the physical and psychological development of an entire generation of children (i.e. about 250 million) is bound to suffer from it (De Pee et al., 2010); education becomes less affordable to larger sectors of the population in affluent countries ("Crescere un bambino?," 2010); healthcare provision is threatened by budgetary concerns arising from public bailouts of bankrupt private banks (Triggle, 2009), despite the IMF's unusual advice not to cut public expenditures and keep current taxation levels (Iezzi, 2008; Elliott, 2010b); and so are the promotion and diffusion of cultural activities and scientific knowledge even in countries that are said to have been affected only limitedly by the crisis (“Actors condemn Harper's culture cuts," 2008).

${ }^{44}$ Cf. General Comment No. 3, 1990, para. 8 quoted above, at p. 11 and accompanying text.

45 The 2008 "credit crunch" was due to "toxic assets" created and traded for profit by the world's largest financial institutions, which were rescued from the brink of bankruptcy by massive state intervention (Stiglitz, 2010) and henceforth allowed to: (a) lend money for profit to taxpayers whose tax-money had saved them; (b) deny money to public bodies to the point of nearbankruptcy (e.g. the US State of California); (c) pay bonuses to executives responsible for the "crunch" due to "toxic assets"; and (d) speculate against and/or force states to cut public spending via control of treasury bonds and other securities. Whilst (a) and (c) contradict the capitalist ethos, (b) and (d) have obvious negative implications for publicly funded civil commons.

${ }^{46}$ States which have signed a treaty undertake not to undermine its object and purpose, pending ratification (VCLT, 1980, article 18).

${ }^{47}$ The protocol will come into force when 10 states have ratified it, thus giving individuals and groups within those jurisdictions the right to bring communications indicating violations of their rights to the ESCR Committee (OP-ICESCR, 2008, article 18).

48 The ICESCR here refers explicitly to two of the "four freedoms" articulated by F.D. Roosevelt (1941), which formed the foundation of the UDHR (Whelan and Donnelly, 2007). The preamble of a treaty is not legally binding on state parties per se, but forms part of its context and indicates

Studies in Social Justice, Volume 5, Issue 1, 2011 
its object and purpose. Therefore, when interpreting the substantive articles, reference to the preamble can be made (VCLT, 1980, article 13).

49 Non-state actors, as well as states, are prohibited from relying on any of the rights within the ICESCR to deny others the same (ICESCR, 1966, article 5(1)).

50 At the implicit heart of biology and medicine there are grounds from which one may deduce universal criteria of planetary and human life-needs, hence guidelines for public welfare too. However, today's "life sciences" epitomise the life-blindness of much scholarship and scientific research, for this term includes life-destructive praxes such as the corporate stipulation of new disorders and the development of biological weapons.

51 The data requests have been criticized for being too detailed and burdensome, in particular for developing states (Chapman and Russell, 2002).

52 Jordan (2004b) criticizes McMurtry for producing different indexes and explains this fact by suggesting that whereas most biological needs are invariant, emotional and thought-related ones are not so. Rubino (2010) claims Jordan: (a) to be confusing invariant emotional and thoughtrelated needs with the varying degrees of awareness of them and the many means by which to satisfy them; as well as (b) to be missing the scientifically appropriate openness of McMurtry's WBI to empirical correction and theoretical amelioration.

53 "Shall" is used to indicate a binding state obligation and the use of "everyone" indicates that the obligations of state parties are to all world inhabitants, not only those in the home state, nor even only those inhabitants living within other state parties. Also, the ESCR Committee goes further, relying on articles 55 and 56 as well as the ICESCR to state that: "international cooperation for development and thus for the realization of economic, social, and cultural rights is an obligation of all States" (General Comment No. 3, para.14). In other words, the Committee does not only claim that states should take the covenant into account when engaging in development cooperation but that development cooperation itself is an obligation, not a discretion for members of the UN.

54 Noonan (2006) observes that needs balance one another, as, say, the need for liquid fluids is eventually countered by the need to urinate, or the need to be educated, if unrestrained by the needs to properly rest and socialize, will eventually turn into unhealthy ivory-tower bookwormlike existence. Needs, unlike wants, are satiable. However, life-enablement can progress farther than the perfect satisfaction of needs, for it is possible to think of an impeccably sustainable worldwide community of healthy, happy, educated human beings, who test the limits and improve upon athletic ability, explore at ease the pinnacles of aesthetic bliss, and dwell passionately yet wisely the utter depths of learning. Perhaps, this was the ideal horizon towards which the drafters of the ICESCR dreamt for humanity to be able to advance, after experiencing the Great Depression and its most abhorrent child, the Second World War.

${ }^{55}$ General Comments No. 4, 1991, para. 8(g), 12, 1999, para. 8 and 14, 2000, para. 12(c) focus upon the importance of the cultural appropriateness of housing, food and healthcare respectively.

${ }^{56}$ In blatant opposition to the life-aims of the ICESCR, primary education is not available for free to millions of African children (Transparency International, 2010) and labour unionization in some developed countries has been reduced to a tiny fragment of the total workforce (Friedman, 2008).

57 An ongoing effort in this direction can be found in Giovannini, Hall, Morrone, and Ranuzzi (2009), who are developing an alternative framework to measure the progress of societies for the OECD.

${ }^{58}$ To these all, McMurtry (2009-10) adds a theoretical foundation, which perhaps philosophy alone can produce. Still, it is significant that attempts have been made to evaluate performance in ways that differ from those of standard money-bound criteria (e.g. "full employment" in Keynesian economics).

59 Although the ICESCR and the ESCR Committee are ecumenical regarding the type of economic system employed by a state to realize, progressively, the treaty, the committee expresses doubts that rights can be fulfilled entirely for all in a wholly unregulated market and recommends that in the case of privatization, the state ensure some back-up protection for vulnerable groups (e.g. General Comment No. 3, 1990, para. 8, General Comment No. 5, 1994, para. 11-12, General Comment No. 14, 2000, para. 35, General Comment No. 18, 2005, para. 25).

${ }^{60}$ Jonas' work, especially Jonas (1984), adds the awareness of life-destruction to the understanding of modern science-technology, whose study qua binomial was initiated by his famous mentor, Martin Heidegger (1982).

61 As this article is being completed, news agencies report of the $\$ 1.2 \mathrm{~m}$ fine imposed on Londonbased Trafigura for illegally exporting toxic waste to Ivory Coast, thus causing illness to about 
30,000 local inhabitants. Possibly, Trafigura had attempted to adhere to the waste-dumping logic sanctioned by Lawrence Summers.

${ }^{62}$ Neither the ICESCR nor the ICCPR contain provisions for denunciation (withdrawal) by states parties, in contrast to the vast majority of treaties in other fields of international law.

${ }^{63}$ General Comment No 19, 2007, para. 11, recognizing the need for social security schemes to be sustainable "to ensure that the right can be realized for present and future generations."

64 Revealing of the degree of planetary exhaustion is the recent proposal by Maldivan President Mohamed Nashed to create a fund whereby to purchase a new homeland for his nation's inhabitants, as their archipelago is foreseen to disappear under water in the near future ("Le Maldive,” 2008).

65 The mind-lock of leading economists and policy-makers is exemplified ostensibly by the notion that some countries were affected less severely by the "credit crunch" of 2008 because of "backward" banking systems that were more tightly regulated and/or less prone to speculation (Draghi, 2008).

${ }^{66}$ Whereas money was created by central banks across the globe to salvage the international financial system from itself, any such money-creation has been resisted for the past thirty years as inflationary and irresponsible, especially if prompted for environmental and/or social aims (Halimi, 2008; "Threat of inflation," 2009).

${ }^{67}$ Money-demand does not determine the ranking of different options amongst private agents alone. Typically, in capitalist countries, money-demand has been driving the behaviour of public institutions as well. The need for food and shelter of millions of Third-World sub-Saharans carries little money-demand, whereas the First-World's middle-classes' desire to travel across the globe carries much more. As a result, First-World states subsidize private enterprises designing new aircraft engines more generously than they fund aid programmes for African countries (European Commission, 2007; “Panel Urges G-8,” 2008).

68 The absence of any life-grounded goal for this self-replication of money-sequences is one of the crucial reasons why McMurtry (1999) claims capitalism to have reached its "cancer stage” (cf. the title of the book). In its systemic patterns of agency, this self-replication of money-sequences mimics the life-disconnected self-replication of cancerous cells within a living host. A second reason is that this self-replication of money-sequences, exactly like the sprawling of cancerous cells, leads eventually to loss of organic capacity, given that planetary life support systems and societies' civil commons have been stripped visibly and regularly in order to allow further selfreplication of money-sequences. A third reason is that societies' civil commons such as publicly elected governments, business schools, and regional development agencies have failed to perceive and respond to the ongoing assault, or actively contributed to it (Chomsky, 2003), analogously to the immune defences of a living organism that do not recognize the ongoing pathology for what it is.

\section{References}

A decade of high unemployment is looming (2009, December 27). Msnbc Business. Retrieved from http://www.msnbc.msn.com/id/34601256/

Aarnio, A. (1991). Statutory interpretation in Finland. In D.N. MacCormick and R.S. Summers (Eds.), Interpreting statutes. A comparative study (pp. 123-170). Aldershot: Dartmouth.

Actors condemn Harper's culture cuts (2008, September 24). CBC News. Retrieved from http://www.cbc.ca/news/canadavotes/story/2008/09/24/artist-protests.html

Agamben, G. (1998). Homo sacer: Sovereign power and bare life. Stanford: Stanford University Press.

Agamben, G. (2005). State of exception. Chicago: University of Chicago Press.

Alfredsson, G., \& Eide, A. (1999). The universal declaration of human rights: A common standard of achievement, The Hague: Kluwer.

Allarme mense, qualità a rischio (2008, November 12). La Repubblica. Retrieved from http://www.repubblica.it/2008/11/sezioni/cronaca/mense-rischi/mense-rischi/mense-rischi.html

Studies in Social Justice, Volume 5, Issue 1, 2011 
Allen, R., \& Baruchello, G. (2007). Life responsibility versus mechanical reductionism: Western worldviews of nature from pantheism to positivism. In Encyclopedia of life support systems. Retrieved from http://www.eolss.net

Alston, P. (2009). Putting economic, social and cultural rights back on the agenda of the United States. New York university centre for human rights and global justice, Working Paper Nov. 22, 2009. Retrieved from http://www.chrgj.org/publications/docs/wp/Alston\%20Spring\%2009.pdf

Alston, P., \& Quinn, G. (1987). The nature and scope of states parties' obligations under the International Covenant on Economic, Social and Cultural Rights, Human Rights Quarterly, 9, 156-229.

Angell, M. (2004, June 15). The truth about the drug companies. The New York Review of Books, 51(12). Retrieved from http://www.nybooks.com/articles/17244

Arbour, L. (2006). Economic and social justice for societies in transition. New York university centre for human rights and global justice, Working Paper No. 10

Retrieved from http://www.chrgj.org/publications/docs/wp/WPS_NYU_CHRGJ_Arbour_\%20Final.pdf

Ato, S. (2006). Deferring to difference, cultivating the civil commons, honouring humanity: What's the left-universalist to do? Humanitas, IV, 1-12.

Ban, K. (2009, May 22). UN Secretary-General Ban Ki-moon's message for the World Environment Day. [SG/SM/12265 ENV/DEV/1055 OBV/788]. Retrieved from http://www.un.org/News/Press/docs/2009/sgsm12265.doc.htm

Barkham, P. (2010, May 26). The victims of Ireland's economic collapse. The Guardian. Retrieved from http://www.guardian.co.uk/world/2010/may/26/ireland-economic-collapse

Baruchello, G. (2005). Notes on pessimism. Appraisal, 5(3), 148-150 and 159-160.

Baruchello, G. (2007a). Mechanism, Galileo's animale, and Heidegger's Gestell: Reflections on the lifelessness of modern science. In C. Tandy (Ed.), Death and anti-death, volume 4 (pp. 29-66). Palo Alto: Ria University Press.

Baruchello, G. (2007b). Western philosophy and the life-ground. In Encyclopedia of life support systems. Retrieved from http://www.eolss.net

Baruchello, G. (2008). Deadly economics: Reflections on the neoclassical paradigm. In C. Tandy (Ed.), Death and anti-death, volume 5 (pp. 65-132). Palo Alto, CA: Ria University Press.

Baruchello, G. (2009). Good and bad capitalism: Re-thinking value, human needs, and the aims of economic activity. Economics, Management, and Financial Markets, 4(3), 125-169.

Baruchello, G. and Lintner, V. (2009). Life and death economics: A dialogue. In C. Tandy (Ed.), Death and anti-death, volume 6 (pp. 33-52). Palo Alto: Ria University Press.

Basu, K. (2008, November 17). China and India and world recession. BBC News. Retrieved from http://news.bbc.co.uk/2/hi/south_asia/7733797.stm

Belgium v Spain. (1970) [Barcelona Traction: Case concerning the Barcelona Traction, light and power company, Limited (merits), 1970 International Court of Justice Reports 3 (February 5)]. Retrieved from http://www.icj-cij.org/docket/files/50/5387.pdf

Berlin, I. (1969). Four essays on liberty. Oxford: Oxford University Press.

Bhagwati, J. (2002). Coping with antiglobalization. Foreign Affairs, 81(1), 2-7.

Boffetta, P. (2006). Human cancer from environmental pollutants: The epidemiological evidence. Mutation Research/Genetic Toxicology and Environmental Mutagenesis, 608(2), 157-162.

Boltvinik, J. (2007). Elementos para la crítica de la economía política de la pobreza, Desacatos. Revista de antropología social, 23, January-April.

Budget cuts threaten opera house future (2008, December 26). ThinkSpain. Retrieved from http://www.thinkspain.com/news-spain/15876/budget-cuts-threaten-opera-house-future

Bunting, M. (2004), Willing slaves. How the overwork culture is ruling our lives. London: HarperCollins.

Bunyard, P. (Ed.). (1996). Gaia in action - Science of the living earth. Edinburgh: Floris Books.

Castoriadis, C. (1997a). The 'rationality' of capitalism. In C. Castoriadis, Figures of the thinkable (pp. 81122). Retrieved from http://www.costis.org/x/castoriadis/index.asp

Castoriadis, C. (1997b). World in fragments. Writings on politics, society, psychoanalysis, and the imagination. Stanford: Stanford University Press.

Cazzullo, A. (2009, March 10). Tremonti e il G8. Corriere della sera.it. Retrieved from http://www.corriere.it/politica/09_marzo_10/aldo_cazzullo_tremonti_manifesto_g8_0023d768-0d4611de-82af-00144f02aabc.shtml

Certification case (1996). [Ex parte Chairman of the Constitutional Assembly. In re Certification of the Constitution of the Republic of South Africa 1996 (4) SA 744 (South Africa)]. Retrieved from http://www.constitutionalcourt.org.za/uhtbin/cgisirsi/IndU35IdW0/MAIN/108830009/9

Chapman, A., \& Russell, S. (2002). Introduction. In A. Chapman \& S. Russell (Eds.), Core obligations: Building a framework for economic, social and cultural rights (pp. 1-20). Antwerp: Intersentia. 
Chomsky, N. (2003). Understanding power. London: Vintage.

Chossudovsky, M. (1996). Dismantling Yugoslavia, recolonising Bosnia. Retrieved from http://www.ess.uwe.ac.uk/Kosovo/Kosovo-controversies4.html

Clorfene-Casten, L. (1996). Breast cancer: poisons, profits and prevention. Monroe, Maine: Common Courage Press.

COMER - Committee on Monetary and Economic Reform, Summer 1996.

Cordero, J. (2009, June 5). Al menos 34 muertos por las protestas indígenas en Perú. Un proyecto de ley enfrenta a la policía con las comunidades en una zona de la Amazonia. El País. Retrieved from http://www.elpais.com/articulo/internacional/34/muertos/protestas/indigenas/Peru/elpepuint/20090605e lpepuint_19/Tes

Craven, M.C.R. (1995). The International Covenant on Economic, Social, and Cultural Rights: A perspective on its development. Oxford: Clarendon Press.

Crescere un bambino? Roba da ricchi (2010, February 23). La Stampa.it. Retrieved from http://www.lastampa.it/redazione/cmsSezioni/societa/201002articoli/52530girata.asp

D’Argenio, A. (2008, November 5). L’Europa invasa dalla cocaina. La Repubblica. Retrieved from http://www.repubblica.it/2008/11/sezioni/cronaca/ue-cocaina/ue-cocaina/ue-cocaina.html

Dartmouth Common Master Plan. (2009). Retrieved from http://www.halifax.ca/RealPropertyPlanning/DCMP/documents/DCMPTOC_DraftNov2009.pdf

De Pee, S. et al. (2010). How to ensure nutrition security in the global economic crisis to protect and enhance development of young children and our common future. The Journal of Nutrition, 140(1), 138S-142S.

Deutsch, M., Feschbach, M., \& Friendly Jr., A. (1968). Ecocide in the USSR: The looming disaster in soviet health and environment. New York: Basic Books.

Dickinson, T., Becerra, T.A. \& Lewis, S. (Eds.). (2009). Democracy works: Joining theory and action to foster global change. Herndon: Paradigm Publishers.

Doyal, L., \& Gough, I. (1991). A theory of human need. London: MacMillan.

Draghi, M. (2008). Giornata mondiale del risparmio del 2008. [Presentation by the Governor of the Bank of Italy at the national meeting of ACRI on the annual world day for savings, October 31, 2008]. Retrieved from http://www.repubblica.it

ECOSOC. (1985). Review of the composition, organization and administrative arrangements of the Sessional Working Group of Governmental Experts on the Implementation of the International Covenant on Economic, Social and Cultural Rights [Resolution No. 1985/17, May 28, 1985].

Eide, A. (2001). Economic, social and cultural rights as human rights. In A. Eide, C. Krause, \& A. Rosas (Eds.), Economic, social and cultural rights: A textbook, $2^{\text {nd }}$ ed. (pp. 10-28). The Hague: Kluwer.

Elliott, L. (2010a, February 8). Ireland's suffering offers a glimpse of Britain's future under the Tories. The Guardian. Retrieved from http://www.guardian.co.uk/business/2010/feb/08/ireland-sufferingausterity-measures

Elliott, L. (2010b, April 21). Western economies too weak for spending cuts, IMF warns. The Guardian. Retrieved from

http://www.google.co.uk/search?hl=en\&q=Western+economies+too+weak+for+spending+cuts\%2C+IMF +warns\&meta=\&rlz=1I7ADRA_en

Elliott, L., \& Atkinson, D. (2008). The gods that failed. How blind faith in markets has cost us our future. London: The Bodley Head.

ESCR Committee. (1990-2009). Committee on economic, social and cultural rights: Reports on sessions [U.N. ESCOR, Comm. On Econ., Soc. and Cultural Rts., various Sess., Supp. No. 2]. Retrieved from http://tb.ohchr.org/default.aspx

ESCR Committee (2002). Committee on economic, social and cultural rights: Report on the twenty-fifth, twenty-sixth and twenty-seventh sessions [U.N. ESCOR, Comm. On Econ., Soc. and Cultural Rts., 58 Sess., Supp. No. 2, U.N. Doc. E/2002/22]. Retrieved from http://tb.ohchr.org/default.aspx

ESCR Committee (2001). Poverty and the international covenant on economic, social and cultural rights [Statement adopted by the Committee on Economic, Social and Cultural Rights on 4 May 2001, U.N. Doc. E/C.12/2001/10]. Retrieved from http://www.unhchr.ch/tbs/doc.nsf/(Symbol)/E.C.12.2001.10.En

Espo, D. (2010, October 16). Republicans find peril and potential as tea party movement reshapes political landscape. Star Tribune. Retrieved from http://www.startribune.com/politics/105092684.html

Esposito, R. (2004). Bíos: Biopolitica e filosofia, Turin: Einaudi.

Esposito, R. (2005). Biopolitica, immunità, comunità. In A. Cutro (Ed.), Biopolitica: Storia e attualità di un concetto. Verona: Ombre Corte, 158-167.

Studies in Social Justice, Volume 5, Issue 1, 2011 
European Commission. (2007, September 26). The WTO Boeing-Airbus dispute: Details of the US subsidies to Boeing challenged by the EU [EU trade issues]. Retrieved from http://ec.europa.eu/trade/issues/respectrules/dispute/pr260907_en.htm

Fao: 963 milioni senza cibo (2008, December 10). City, p. 4A.

Finlay, L.M. (2000). All the world's a stooge? Globalization as aesthetic system. Topia. A Canadian Journal of Cultural Studies, 2000/4, 39-51.

Florby, G., Shackleton, M. \& Suhonen, K. (Eds.). (2009). Introduction to Canada: images of a post/national society. Canadian Studies, 19, 1-22.

Florio, M. (2004). The great divestiture. Evaluating the welfare impact of the British privatizations 19791997. Cambridge, Mass. and London, UK: The MIT Press.

Foucault, M. (2008). The birth of biopolitics. Lectures at the College of France 1978-79. New York: Palgrave MacMillan.

Friedman, G. (2008). Labor unions in the United States. In EH.Net Encyclopedia. Retrieved from http://eh.net/encyclopedia/article/friedman.unions.us

Gaggi, M. (2008, November 7). Ibm e i big Usa: chi ha paura del Barack 'statalista'. Corriere della sera. Retrieved from Governo Italiano: rassegna stampa: http://rassegna.governo.it/rs_pdf/pdf/JSM/JSMF0.pdf

Galeano, E. (2000). Upside down. A primer for the looking-glass world. New York: Picador.

Galbraith, J. K. (1977). The age of uncertainty. London: BBC.

Galbraith, J. K. (2007). The new industrial state, with a new foreword by James K. Galbraith. Princeton and Oxford: Princeton University Press.

General Comments by the Committee on Economic, Social and Cultural Rights. (ESCR Committee, 19892009). Compilation of general comments and general recommendations adopted by human rights treaty bodies [cited in the article as:

General Comment No. 2. (1990). International technical assistance measures

General Comment No. 3. (1990). The nature of states parties' obligations

General Comment No. 4. (1991). The right to adequate housing

General Comment No. 5. (1994). Persons with disabilities

General Comment No. 6. (1995). The economic, social and cultural rights of older persons

General Comment No. 12. (1999). The right to adequate food

General Comment No. 13. (1999). The right to education

General Comment No. 14. (2000). The right to the highest attainable standard of health

General Comment No. 15. (2002). The right to water

General Comment No. 18. (2005). The right to work

General Comment No. 19. (2007). The right to social security. Retrieved from: http://daccess-dds-ny.un.org/doc/UNDOC/GEN/G08/422/35/PDF/G0842235.pdf?OpenElement

General Comment No. 21. (2009). The right of everyone to take part in cultural life http://www2.ohchr.org/english/bodies/cescr/docs/gc/E-C-12-GC-21.doc]

Giovannini, E., Hall, J., Morrone, A., \& Ranuzzi, G. (2009). A framework to measure the progress of societies [Draft OECD working paper]. Retrieved from http://www.oecd.org/dataoecd/40/46/43631612.pdf

Glyn, A. (2006) Capitalism unleashed. Finance, globalization, and welfare. Oxford: Oxford University Press.

Halimi, S. (2008, November). Thinking the unthinkable. Le Monde Diplomatique, pp. 1A, 5A.

Hardin, G. (1968). The tragedy of the commons. Science, 162, 1243-1248.

Heidegger, H. (1982). The question concerning technology and other essays. New York: Harper.

Hobsbawm, E. (1995). The age of extremes, 1914-1991. London: Abacus.

Hobsbawm, E. (2000). The new century. In conversation with Antonio Polito. London: Abacus.

Hodgson, B.J. (2001). Can the beast be tamed? Reflections on John McMurtry's Unequal freedoms: The global market as an ethical system. Journal of Business Ethics, 33(1), 71-78.

Hodgson, G.M. (1993). Economics and evolution: Bringing back life into economics. Cambridge: Polity Press.

I bisogni. (2007, January 11). Retrieved January 22, 2009, from http://doc.studenti.it/riassunto/diritto/bisogni-loro-classificazione.html

ICCPR. (1966). International Covenant on Civil and Political Rights [adopted 16 Dec. 1966, G.A. Res. 2200A, U.N. GAOR, 21st Sess., Supp. No. 16, at 52, U.N. Doc. A/6316 (1966), entered into force Mar. 23, 1976]. Retrieved from http://www2.ohchr.org/english/law/ccpr.htm 
ICCPR-OP1. (1966). Optional protocol to the ICCPR [GA Res. 2200A (XXI), 21 UN GAOR Supp. (No. 16) at 59, UN Doc. A/6316 (1966); 999 UNTS 302]. Retrieved from http://www2.ohchr.org/english/law/ccpr-one.htm

ICESCR. (1966). International Covenant on Economic, Social and Cultural Rights [adopted 16 Dec. 1966, G.A. Res. 2200A, U.N. GAOR, 21st Sess., Supp. No. 16, at 49, U.N. Doc. A/6316 (1966), entered into force Jan. 3, 1976]. Retrieved from http://www2.ohchr.org/english/law/cescr.htm

Iezzi, L. (2008, December 30). 'Più spese e niente tagli alle tasse' ecco la ricetta anti-crisi dell’Fmi. La Repubblica. Retrieved from http://www.repubblica.it/2008/12/sezioni/economia/crisi-8/ricettafmi/ricetta-fmi.html

International Labour Organization. (2006). Labour inspection 2006 [General surveys by the committee of experts on the application of conventions and recommendations]. Retrieved from http://www.ilo.org/public/english/support/lib/resource/subject/labourinsp.htm

Jefferson, T. (1816). Letter to John Taylor [ME 15:23]. Retrieved from http://etext.virginia.edu/jefferson/quotations/jeff1325.htm

Jefferson, T. (1817). Letter to Josephus B. Stuart [ME 15:112]. Retrieved from http://etext.virginia.edu/jefferson/quotations/jeff1325.htm

Johnston, J. (2003). Who cares about the commons? Capitalism Nature Socialism, 14(4), 1-41.

Johnston, J., Gismondi, M. and Goodman, J. (Eds.). (2006). Nature's revenge: Reclaiming sustainability in an age of corporate globalization. Toronto: Garamond Press.

Jonas, H. (1984). The imperative of responsibility. In search of an ethics for the technological age. Chicago: The University of Chicago Press.

Jonas, H. (1993). Sul razzismo. In H. Jonas, Il concetto di Dio dopo Auscwitz. Una voce ebraica (pp. 4149). Genoa: Il melangolo.

Jordan, B. (2004a). Sex, money and power: The transformation of collective life. Cambridge: Polity Press.

Jordan B., (2004b). Growth to freedom or support to life? Res Publica, 10(2), 193- 205.

Kaara, W. (2005). Statement for a religious leaders' consultation on global poverty. Retrieved from http://www.nationalcathedral.org/pdfs/050911/WahuKaara_Stmt.pdf

Krugman, P. (2010a, February 1). A depressing budget. Message posted to http://krugman.blogs.nytimes.com/2010/02/01/a-depressing-budget/

Krugman, P. (2010b, April 11). Samuelson Memorial. Message posted to http://krugman.blogs.nytimes.com/2010/04/11/samuelson-memorial/

Langford, M. (2009). The justiciability of social rights: From practice to theory, in M. Langford (Ed.) Social rights jurisprudence: Emerging trends in comparative and international law 3 (pp. 3-45) Cambridge: Cambridge University Press.

Langford, M. \& King, J.A. (2009). Committee on economic, social and cultural rights: Past, present and future, in M. Langford (Ed.) Social rights jurisprudence: Emerging trends in comparative and international law 3 (pp. 477-516). Cambridge: Cambridge University Press.

Latouche, S. (2004). La Mégamachine: Raison technoscientifique, raison économique et mythe du progrès. Paris: La découverte.

Latouche, S. (2007). Petit traité de la décroissance sereine. Paris: Mille et une nuits.

Law no. 173/2008 [um ráðstafanir í ríkisfjármálum (2008). Iceland]. Retrieved from http://www.althingi.is/altext/stjt/2008.173.html

Law no. 70/2009 [um ráðstafanir í ríkisfjármálum (2009). Iceland] Retrieved from http://www.althingi.is/altext/stj/2009.070.html

Le Maldive risparmiano per comprarsi una nuova 'patria' (2008, November 10). La Stampa. Retrieved from http://www.lastampa.it/redazione/cmsSezioni/esteri/200811articoli/38055girata.asp

Liebenberg, S. (2009). South Africa: Adjudicating social rights under a transformative constitution. In M. Langford (Ed.), Social rights jurisprudence: Emerging trends in comparative and international law 3 (pp. 75-101). Cambridge: Cambridge University Press.

Lovelock, J. (1979). A new look at gaia. Oxford: Oxford University Press.

'Major Global Downturn' says IMF (2008, October 8). BBC News. Retrieved from http://news.bbc.co.uk/1/hi/business/7659086.stm

Maslow, A. H. (1943). A theory of human motivation. Psychological Review, 50, 1943, 370-396.

May, R. (1969). Value theory and the behavioural sciences. Springfield: Charles C. Thomas.

McDonnell, F. (2009, December 10). Sick Ireland takes a bitter pill. The Guardian. Retrieved from http://www.guardian.co.uk/commentisfree/2009/dec/10/ireland-budget-bitter-pill

McMurtry, J. (1978). The structure of Marx's world-view. Princeton: Princeton University Press.

Studies in Social Justice, Volume 5, Issue 1, 2011 
McMurtry, J. (1998). Unequal freedoms: The global market as an ethical system. Toronto: Garamond Press.

McMurtry, J. (1999). The cancer stage of capitalism. London: Pluto Press.

McMurtry, J. (2002). Value wars: The global market versus the life economy. London: Pluto Press.

McMurtry, J. (2005). Principles of the good life: The primary theorems of economic reason [Unpublished manuscript].

McMurtry, J. (2008). The human vocation: An autobiography of higher education. NordicumMediterraneum, 3(2). Retrieved from http://nome.unak.is/nome2/issues/vol3_2/mcmurtry.html

McMurtry, J. (2009-10). What is good? What is bad? The value of all values across time, place and theories. In Encyclopedia of Life Support Systems. Retrieved from http://www.eolss.net

McMurtry, J. (2010). Economic globalization and ethico-political rights. In D. Callahan, R. Chadwick, P. Singer (Eds.), Encyclopedia of applied ethics. Maryland Heights: Elsevier. [Forthcoming; the final version of this entry was made available to the authors of this article by John McMurtry].

Mook, L., \& Sumner, J. (2008). Knowing what counts: Social accounting for sustainability. [Presentation to the Association of Co-operative Educators (ACE) conference, Ottawa, July 30, 2008]. Retrieved from http://www.ace.coop/portals/0/institute/08/ACE_LaurieMook_SEC_July30_08.pdf

Morrison, A. D. \& Wilhelm, jr., W. J. (2007). Investment banking: Institutions, law and politics. Oxford: Oxford University Press.

Nacci, M. (2009). Su biopolitica, liberaldemocrazia e nazismo si può dire tutto e il contrario. L'Occidente. Retrieved from http://www.loccidentale.it/articolo/biopolitica,+liberaldemocrazia,+nazismo.0065146

Nadjer, Z. (1975).Values and evaluations. Oxford: Clarendon Press.

Narula, S. (2006). The right to food: Holding global actors accountable under international law, Columbia Journal of Transnational Law, 44, 691-800.

Nolan, A., Porter, B., \& Langford, M. (2007). The justiciability of social and economic rights: An updated appraisal. New York University center for human rights and global justice, Working Paper No. 15. Retrieved from http://www.chrgj.org/publications/docs/wp/NolanPorterLangford.pdf

Noonan, J. (2006). Democratic society and human needs. Montreal and Kingston: McGill-Quenn's University Press.

Norberg, J. (2003). In defense of global capitalism. Washington: The Cato Institute.

OECD. (2010). Harmonised Unemployment Rates: News Release: August 2010. Retrieved from http://www.oecd.org/dataoecd/45/21/46175570.pdf

OP-ICESCR. (2008). Optional protocol to the International Covenant on Economic, Social and Cultural Rights [GA res. A/63/435 (Dec. 10, 2008)] Retrieved from http://www2.ohchr.org/english/bodies/cescr/docs/A-RES-63-117.pdf

Orbach, S. (2009). Bodies. London: Profile.

Panel Urges G-8 to Increase Africa Aid (2008, June 15). Washington Post. Retrieved from http://www.washingtonpost.com/wp-dyn/content/article/2008/06/15/AR2008061502081.html

Pauw, J. (2003, February 5). Metered to death: How a water experiment caused riots and a cholera epidemic. The Water Barons. Retrieved from

http://projects.publicintegrity.org/water/report.aspx?aid=49\#

Perry, R. B. (1954). Realms of value. Cambridge: Harvard University Press.

Plant, M. (2008). Food security and the increase in global food prices [Speech delivered at Panama Chamber of Commerce, Industry and Agriculture on June 19, 2008]. Retrieved from http://www.imf.org/external/np/speeches/2008/061908.htm

Posner, R.A. (2010). A failure of capitalism. Message posted to http://correspondents.theatlantic.com/richard_posner/2010/01/

Public accountant: companies thrived on deception (2008, December 18). Iceland Review. Retrieved from https://secure.icelandreview.com/icelandreview/daily_news/?cat_id=16567andew_0_a_id=317203

Putin, V. (2009, January 28). Prime minister Vladimir Putin's speech at the opening ceremony of the $39^{\text {th }}$ World Economic Forum in Davos, Switzerland. Retrieved from http://www.weforum.org/pdf/AM_2009/OpeningAddress_VladimirPutin.pdf

Rampini, F. (2009, February 13). La Cina in controtendenza. Riparte il credito alle imprese. La Repubblica. Retrieved from http://www.repubblica.it/2008/06/rubriche/piazza-asiatica/pechinocontrotendenza/pechino-controtendenza.html

Rescher, N. (1969). Introduction to value theory. Englewood Cliffs: Prentice-Hall.

Richards, E. (2000). The Highland clearances. Edinburgh: Birlinn Books.

Roberts, A. (2006). Water as commodity: Privatization, primitive accumulation and the contradictory relation between neoliberalism and social reproduction [Presented at the conference "The North-South 
Divide and International Studies,” International Studies Association, San Diego, USA]. Retrieved January 16, 2010, from http://www.allacademic.com//meta/p_mla_apa_research_citation/0/9/9/4/5/pages99452/p99452-1.php

Roosevelt, F. D. (1941). The four freedoms speech [January 6, 1941 State of the Union address]. Retrieved from http://americanrhetoric.com/speeches/fdrthefourfreedoms.htm

Rubino, S. (2010). Assiologia dominante: Struttura del neoliberismo tra scienza e superstizione [Laurea degree thesis available at the library of the Faculty of letters and philosophy of the University of Genoa, Italy].

Sarkozy, N. (2010). Speech by M. Nicolas Sarkozy President of the French Republic at the $40^{\text {th }}$ World Economic Forum in Davos, Switzerland, on Wednesday, January 27, 2010. Retrieved from http://www.elysee.fr/documents/index.php?mode=viewandlang=frandcat_id=7andpress_id=3303

Savulescu, J. (2003). Is the sale of body parts wrong? Journal of Medical Ethics, 29(3), 138-9.

Scarfe, A. (2006). Global interdependence, process, and environmental praxis. Revue-E-Journal, 1(1). Retrieved from http://www.ustpaul.ca/Philosophy/revue/articles/2006_scarfe.html

Scott, C., \& Macklem, P. (1992). Constitutional ropes of sand or justiciable guarantees? Social rights in a new South African constitution, University of Pennsylvania Law Review, 14(1), 1-148.

Seager, A. and Elliott, L. (2009, May 12). Unemployment figures chart grim decline that recalls worst moments of the 1980s. The Guardian. Retrieved from http://www.guardian.co.uk/business/2009/may/12/unemployment-figures-march-job-losses

Sen, A. (1992). Inequality re-examined. Oxford: Oxford University Press.

Shackman, G. (2006-9). Understanding the world today [Website of the Global Social Change Research Project], http://gsociology.icaap.org/

Shurville, S. and Brown, H. (2009). Developing collaborative competence in the librarians of the future [Presented at the 2009 ALIA conference]. Retrieved December, 28, 2009, from conferences.alia.org.au/online2009/docs/PresentationC19.ppt

Shurville, S., Brown, T., \& Whitaker, M. (2009). Accommodating the newfound strategic importance of educational technologists within higher education: A critical literature review. Campus-Wide Information Systems, 26(3), 201-231.

Skogly, S.I. (1993). Structural adjustment and development: Human Rights - An agenda for change, Human Rights Quarterly, 15, 751-778.

Smith, K. (2007, April 4). 'Obscenity' of carbon trading. BBC News. Retrieved from http://news.bbc.co.uk/2/hi/science/nature/6132826.stm

Smith, R. (2008, October 21). Financial crisis will hit mental health of the nation. Telegraph.co.uk. Retrieved from http://www.telegraph.co.uk/finance/financetopics/financialcrisis/3235790/Financialcrisis-will-hit-mental-health-of-the-nation-warn-Government-advisors.html

Soros, G. (1998). The crisis of global capitalism: Open society endangered. Jackson: Public Affairs.

Spencer, H. (1860). The social organism. Retrieved from http://www.bolenderinitiatives.com/sociology/herbert-spencer-1820-1903/herbert-spencer-socialorganism-1860 [Printed originally in The Westminster Review, January 1860 and reprinted in Essays: Scientific, Political and Speculative. London and New York, 1892].

State Report Guidelines. (2009). Compilation of Guidelines on the Form and Content of Reports to be Submitted by States Parties to the International Human Rights Treaties, Chapter I: Harmonized Guidelines on Reporting under the International Human Rights Treaties, Including Guidelines on a Core Document and Treaty-Specific Documents, and Appendix 3, at p. 23 (June 3, 2009) [U.N. Doc. HRI/GEN/2/Rev.6].

Steiner, R. (1985). The renewal of the social organism. Herndon: Steiner Books.

Stiglitz, J. (2003). Globalization and its discontents. New York and London: Norton.

Stiglitz, J. (2010). Freefall: Free markets and the sinking of the global economy. London: Allen Lane.

Straume, I. (2008). Freedom and the collective. Nordicum-Mediterraneum, 3(2). Retrieved from http://nome.unak.is/nome2/issues/vol3_2/straume.html

Streeck, W. (2009). Four books on capitalism. Socio-Economic Review, 7(4), 741-754.

Stuckler, D., King, L. P., \& Basu, S. (2008). International monetary fund programs and tuberculosis outcomes in post-communist countries. PLoS Medicine, 5(7). doi: e143.doi:10.1371/journal.pmed.0050143

Sumner, J. (2005). Sustainability and the civil commons: Rural communities in the age of globalization. Toronto: University of Toronto Press.

Studies in Social Justice, Volume 5, Issue 1, 2011 
Sumner, J. (2008). From academic imperialism to the civil commons: Institutional possibilities for responding to the United Nations decade of education for sustainable development. Interchange: A Quarterly Review of Education, 39(1), 77-94.

Swann, C. (2008, April 12). Strauss-Kahn warns food-price inflation may trigger starvation. Bloomberg.com. Retrieved from

http://www.bloomberg.com/apps/news?pid=20601116andsid=aIFgkr_Mr6wAandrefer=africa

Tremlett, G. (2010, April 30). Portuguese workers unite to resist austerity measures. The Guardian. Retrieved from http://www.guardian.co.uk/business/2010/apr/30/portugal-debt-crisis-workers-protests

Threat of inflation sky high (2009, March 22). The Washington Times. Retrieved from http://www.washingtontimes.com/news/2009/mar/22/threat-of-inflation-sky-high/

Tomasevski, K. (2005). Removing obstacles for the right to education. Human Rights Tribune, 11(3), 1216.

Transparency International. (2010). African education watch 2010, Retrieved from http://www.transparency.org/news_room/latest_news/press_releases/2010/2010_02_23_aew_launch_en

Traynor, I. (2009, November 10). Rude awakening for ex-Communist countries as financial crisis made in West hits hardest in East. The Guardian. http:/www.guardian.co.uk/business/2009/nov/10/formercommunist-countries-financial-crisis

Triggle, N. (2009, June 28). Public 'fears NHS spending cuts’ BBC News. Retrieved from http://news.bbc.co.uk/2/hi/health/8119116.stm

Turner, T., \& Brownhill, L. (2004). Why women are at war with Chevron: Nigerian subsistence struggles against the international oil industry. Journal of Asian and African Studies 39(1-2), 63-93.

U.N.: One billion worldwide face starvation (2009, November 15). CNN World. Retrieved from http://www.cnn.com/2009/WORLD/europe/11/15/un.hunger/index.html

Union of Concerned Scientists. (1997). World scientists' call for action [Document presented at the 1997 Kyoto Summit on climate change]. Available from Eolss.org http://www.eolss.net

United Nations. (1945). Charter of the United Nations. Retrieved from http://www.un.org/en/documents/charter/index.shtml

United Nations. (1948). Universal declaration of human rights [G.A. Res. 217A, U.N. GAOR, $3^{\text {rd }}$ Sess., at 71, Supp. No. 13, U.N. Doc. A/811]. Retrieved from http://www.un.org/en/documents/udhr/

United Nations. (2002-10). Encyclopedia of life support systems. Paris and Oxford: Eolss Publishers. Available from Eolss.org http://www.eolss.net

Usa, multa record alla Siemens (2008, December 15). La Repubblica. Retrieved from http:/www.repubblica.it/2008/12/sezioni/economia/siemens-multa/siemens-multa/siemens-multa.html

Vasagar, J. (2010, October 20). Universities alarmed by $40 \%$ cut to teaching budgets. The Guardian. Retrieved from http://www.guardian.co.uk/education/2010/oct/20/spending-review-universityteaching-cuts

VCLT. (1980). Vienna convention on the law of treaties [1155 U.N.T.S. 331, 8 I.L.M. 679, entered into force Jan. 27, 1980]. Retrieved from http://reaties.un.org/doc/Treaties/1980/01/19800127\%200052\%20AM/Ch_XXIII_01p.pdf

Vidal, J. (2008, October 24-30). West rescues banks but fails the world's hungry. The Guardian Weekly, pp. 1-2A.

Vinnumálastofnun (2010, May 12). Staða á vinnumarkaði apríl 2010. Nr. 4/2010 [Icelandic Department of Employment, April 2010 State of the Labour Market]. Retrieved from http://www.vinnumalastofnun.is/files/apr10_853345154.pdf

Weisbrot, M. (2010, April 28). A Baltic future for Greece? The Guardian. Retrieved from http://www.guardian.co.uk/commentisfree/2010/apr/28/greece-financial-crisis

Westhues, K. (1999). If the market is not god, what is? [Presented at the symposium on J. McMurtry, Unequal Freedoms: the Global Market as an Ethical System. Toronto: Garamond, 1998, Congress of the Social Sciences and Humanities, Sherbrooke, Quebec, 5 June 1999]. Retrieved from http://arts.uwaterloo.ca/ kwesthue/mcmurtry.htm

Whelan, D.J., \& Donnelly, J. (2007). The West, economic and social rights, and the global human rights regime: Setting the record straight. Human Rights Quarterly, 29(4), 908-949.

Wiggins, D. (Ed.). (2002). Needs, values, truth. Essays in the philosophy of value. Oxford: Clarendon Press.

Worldwatch Institute. (2009). State of the world 2009. Washington, D.C.: The Worldwatch Institute Press. World Health Organization. (2009). Obesity and overweight. Retrieved from http://www.who.int/dietphysicalactivity/publications/facts/obesity/en/print.html

Ziegler, C.E. (1990). Environmental policy in the USSR. Amherst: University of Massachusetts Press. 